\title{
The Cultivable Bacterial Microbiota Associated to the Medicinal Plant Origanum vulgare L.: From Antibiotic Resistance to Growth-Inhibitory Properties
}

\author{
Lara Mitia Castronovo ${ }^{1}$, Carmela Calonico², Roberta Ascrizzi ${ }^{3}$, Sara Del Duca', \\ Vania Delfino ${ }^{2}$, Sofia Chioccioli ${ }^{1}$, Alberto Vassallo ${ }^{1}$, Iolanda Strozza ${ }^{1}$, Marinella De Leo ${ }^{3}$, \\ Sauro Biffi ${ }^{4}$, Giovanni Bacci' ${ }^{1}$, Patrizia Bogani', Valentina Maggini 1,5, Alessio Mengoni', \\ Luisa Pistelli ${ }^{3}$, Antonella Lo Nostro ${ }^{2}$, Fabio Firenzuoli ${ }^{5}$ and Renato Fani ${ }^{1 \star}$ \\ ${ }^{1}$ Department of Biology, University of Florence, Sesto Fiorentino, Italy, ${ }^{2}$ Department of Health Sciences, University \\ of Florence, Florence, Italy, ${ }^{3}$ Department of Pharmacy, University of Pisa, Pisa, Italy, ${ }^{4}$ Giardino delle Erbe, Casola Valsenio, \\ Italy, ${ }^{5}$ Research and Innovation Center in Phytotherapy and Integrated Medicine - CERFIT Careggi University Hospital, \\ Florence, Italy
}

OPEN ACCESS

Edited by:

Paolo Visca,

Roma Tre University, Italy

Reviewed by:

Christian Milani,

University of Parma, Italy

Daniela Minerdi,

University of Turin, Italy

*Correspondence:

Renato Fani

renato.fani@unifi.it

Specialty section:

This article was submitted to Antimicrobials, Resistance

and Chemotherapy,

a section of the journal

Frontiers in Microbiology

Received: 17 February 2020

Accepted: 09 April 2020

Published: 08 May 2020

Citation:

Castronovo LM, Calonico C Ascrizzi R, Del Duca S, Delfino V, Chioccioli S, Vassallo A, Strozza I, De Leo M, Biffi S, Bacci G, Bogani P, Maggini V, Mengoni A, Pistelli L,

Lo Nostro A, Firenzuoli F and Fani $R$ (2020) The Cultivable Bacteria

Microbiota Associated to the Medicinal Plant Origanum vulgare L.:

From Antibiotic Resistance

to Growth-Inhibitory Properties.

Front. Microbiol. 11:862.

doi: 10.3389/fmicb.2020.00862
The insurgence of antibiotic resistance and emergence of multidrug-resistant (MDR) pathogens prioritize research to discover new antimicrobials. In this context, medicinal plants produce bioactive compounds of pharmacological interest: some extracts have antimicrobial properties that can contrast different pathogens. For such a purpose, Origanum vulgare L. (Lamiaceae family) is a medicinal aromatic plant, whose essential oil (EO) is recognized for its antiseptic, antimicrobial and antiviral activities. The cultivable bacteria from different compartments (i.e., flower, leaf, stem and soil) were isolated in order to: (i) characterize the bacterial microbiota associated to the plant, determining the forces responsible for the structuring of its composition (by evaluation of cross inhibition); (ii) investigate if bacterial endophytes demonstrate antimicrobial activities against human pathogens. A pool of plants belonging to O. vulgare species was collected and the specimen chemotype was defined by hydrodistillation of its essential oil. The isolation of plant associated bacteria was performed from the four compartments. Microbiota was further characterized through a culture-independent approach and next-generation sequencing analysis, as well. Isolates were molecularly typed by Random Amplified Polymorphic DNA (RAPD) profiling and taxonomically assigned by 165 rRNA gene sequencing. Antibiotic resistance profiles of isolates and pairwise cross-inhibition of isolates on agar plates (i.e., antagonistic interactions) were also assessed. High level of diversity of bacterial isolates was detected at both genus and strain level in all different compartments. Most strains were tolerant against common antibiotics; moreover, they produced antagonistic patterns of interactions mainly with strains from different compartments with respect to that of original isolation. Strains that exhibited high inhibitory properties were further tested against human pathogens, revealing a strong capacity to inhibit the growth of strains resistant to several antibiotics. In 
conclusion, this study regarded the characterization of $O$. vulgare L. chemotype and of the bacterial communities associated to this medicinal plant, also allowing the evaluation of antibiotic resistance and antagonistic interactions. This study provided the bases for further analyses on the possible involvement of endophytic bacteria in the production of antimicrobial molecules that could have an important role in clinical and therapeutic applications.

Keywords: antimicrobial compounds, medicinal plants, Origanum vulgare, endophytic bacteria, antibiotic resistance

\section{INTRODUCTION}

Increasing antibiotic resistance, due to an overuse of antibiotics, and emergence of multidrug-resistant (MDR) pathogens prioritize research to discover new antimicrobials. The use of plants or their derivatives for prevention and treatment of various health ailments and infections is in practice from immemorial time (Sahoo et al., 2010): in fact, some plant extracts have antimicrobial properties able to affect different pathogens (Shityakova et al., 2019).

Microorganisms are naturally associated to plants in different ways (Reinhold-Hurek and Hurek, 2011). According to a widely used definition, "endophytic bacteria and fungi internally colonize the host tissues, sometimes in high numbers, without damaging the host or eliciting symptoms of plant disease" (Quispel, 1992). Most of the microorganisms inhabiting plants are important for the host's development and health, despite, sometimes they could also be neutral (Mendes et al., 2013; Philippot et al., 2013).

Increasing knowledge indicates that microbes and/or their interactions with the host are responsible for the synthesis of natural products (Gunatilaka, 2006): for several medicinal plants, according to Köberl et al. (2013), "it is presumed that the plantassociated microbiome, especially the complex community of the endomicrobiome, is directly or indirectly involved in the production of bioactive phytochemicals". Indeed, endophytic microorganisms play an important role in searching for natural bioactive compounds, with potential use in the health sector and in drug discovery (Lam, 2007). It is well known that, within plant diversity, a distinctive microbiota is harbored by medicinal plant species due to their structurally divergent and unique secondary metabolites (Qi et al., 2012).

Origanum vulgare $\mathrm{L}$. is a medicinal aromatic plant belonging to the Lamiaceae family, which comprises many essential oil (EO) producing species. $O$. vulgare is morphologically considered to be one of the most variable species within the genus Origanum. Moreover, its variability is also exhibited in the chemotype, which is highly influenced by the plant growth environment. The most represented compounds in oregano EO are phenolic monoterpenes, such as carvacrol and thymol (Werker et al., 1985; De Mastro et al., 2017), followed by linalool and linalyl acetate (De Mastro et al., 2017). Thymol and carvacrol have been reported to exert a substantial inhibitory activity against microbes (Lambert et al., 2001): in fact, it is known that the antibacterial properties of $\mathrm{EO}$ are mainly due to its phenolic compounds (Cosentino et al., 1999). Other published studies report EO compositions rich in sesquiterpene hydrocarbons, such as germacrene $\mathrm{D}$ and $\beta$-caryophyllene (Mockute et al., 2001). These two compounds are major components also in other medicinal plants EOs, such as those of Cedrus libani A. Rich. and Artemisia vulgaris L., and they are known to act as antimicrobial, anesthetic and anti-inflammatory compounds, with cytotoxic activity against several cancer cell lines (Saab et al., 2018; Malik et al., 2019). According to Checcucci et al. (2017), the plant species (medicinal or aromatic ones) that produce EOs could represent a suitable model for "testing the hypothesis of an effect of the endophyte-microbiome dichotomy on the production of EOs and, consequently, of a colonization of plant tissues by bacteria resistant to these oils," as well as the role of plant-bacteria interaction in the modulation of medicinal plant secondary metabolism (Maggini et al., 2019a,b, 2020).

In this work, the chemotype of O. vulgare $\mathrm{EO}$ was determined and the cultivable bacteria from different compartments (flower, leaf, stem and soil) were isolated. The main goals were (i) to characterize the bacterial microbiota associated to the plant, determining the forces responsible for the structuring of its composition (by evaluation of cross inhibition); (ii) to investigate if bacterial endophytes demonstrate antimicrobial activities against human pathogens.

\section{MATERIALS AND METHODS}

\section{Hydrodistillation of the Essential Oil}

A pool of three plants of $O$. vulgare L. cultivated in an openair common garden at the "Giardino delle Erbe - Augusto Rinaldi Ceroni," Casola Valsenio (Ravenna, Italy), were collected in July 2018. $1 \mathrm{~kg}$ of above ground tissues was distilled. The steam distillation of EO was carried out at the Giardino delle Erbe (Casola Valsenio, RA, Italy), following the method described in Hanci et al. (2003).

\section{Determination of the Essential Oil Composition}

The pure EO was diluted at $5 \%$ in HPLC-grade $n$-hexane and then injected in the GC/EI-MS apparatus. The GC/EIMS analyses were performed with a Varian CP-3800 apparatus equipped with a DB-5 capillary column $(30 \mathrm{~m} \times 0.25 \mathrm{~mm}$ i. d., film thickness $0.25 \mu \mathrm{m}$ ) and a Varian Saturn 2000 ion-trap mass detector. The oven temperature was programmed rising from 60 to $240^{\circ} \mathrm{C}$ at $3^{\circ} \mathrm{C} / \mathrm{min}$. The set temperatures were as 
follows: injector temperature, $220^{\circ} \mathrm{C}$; transfer-line temperature, $240^{\circ} \mathrm{C}$. The carrier gas was $\mathrm{He}$, at $1 \mathrm{ml} / \mathrm{min}$ flow. The injection volume was set at $1 \mu \mathrm{l}$. The acquisition was performed with the following parameters: full scan, with a scan range of 35-300 $\mathrm{m} / z$; scan time: $1.0 \mathrm{~s}$; threshold: 1 count. The identification of the constituents was based on the comparison of their retention times $\left(t_{R}\right)$ with those of pure reference samples and their linear retention indices (LRIs), which were determined relatively to the $t_{R}$ of a series of $n$-alkanes. The detected mass spectra were compared with those listed in the commercial libraries NIST 14 and ADAMS, as well as in a homemade mass-spectral library, built up from pure substances and components of commercial essential oils of known compositions, and in MS literature data (Masada, 1976; Jennings and Shibamoto, 1982; Davies, 1990; Swigar and Silverstein, 1992; Adams, 1995; Adams et al., 1997).

\section{Sampling of $O$. vulgare and Plant-Associated Bacteria Extraction}

From the same pool of plants of $O$. vulgare used for hydrodistillation, plant anatomical parts (i.e., flower, leaf, stem) and soil near the plant roots (bulk soil) were separately collected and treated as independent samples. Flowers were grouped and pooled, as well as the stems and leaves. $1 \mathrm{~g}$ of fresh tissue from each pool was surface sterilized with $1 \% \mathrm{v} / \mathrm{v} \mathrm{HClO}$ in a sterile $50 \mathrm{ml}$ tube at room temperature in order to remove the epiphytic bacteria, as described in Chiellini et al. (2014). After this, samples were washed three times with sterile water, and then they were pottered in a sterile mortar with the addition of $2 \mathrm{ml}$ of $0.9 \% \mathrm{w} / \mathrm{v}$ $\mathrm{NaCl}$ sterile solution. Water used for the last wash was plated on TSA to verify sterility of sample external surface. Bulk soil was treated separately at room temperature for $1 \mathrm{~h}$ with $20 \mathrm{ml}$ of $10 \mathrm{mM} \mathrm{Mg} \mathrm{MO}_{4}$ in a $50 \mathrm{ml}$ sterile tube under shaking, to allow the detachment of bacteria from soil particles.

\section{Extraction of Genomic DNA and NGS Sequence Analysis}

Genomic DNA was extracted from flower, leaf and stem samples using PowerLyzer $^{\circledR}$ PowerSoil $^{\circledR}$ DNA Isolation Kit (MO BIO laboratories, Inc., Carlsbad, CA, United States) following the manufacturer's instruction. Hypervariable regions of bacterial 16S rRNA gene (V1-V9) (Chakravorty et al., 2007; Petrosino et al., 2009) were used as molecular markers for bacterial identification in HTS analysis (Huse et al., 2008). In this study, the V3-V4 regions were sequenced using the primer $341 \mathrm{~F}$ and $805 \mathrm{R}$ (Herlemann et al., 2011) according to the protocol reported in the $16 \mathrm{~S}$ Metagenomic Sequencing Library Preparation protocol from Illumina (Kozich et al., 2013). Library preparation and demultiplexing were performed following Illumina's standard pipeline (Caporaso et al., 2012). Libraries were sequenced in a single run using Illumina MiSeq technology with pair-end sequencing strategy with MiSeq Reagent Kit v3. Library construction and sequencing were performed by an external company (BMR Genomics, Padua, Italy). Sequence files have been submitted in the NCBI sequence read archive (SRA) and are available under the accession PRJNA606513.

\section{Amplicon Sequence Variant Inference}

Sequences were clustered into ASVs using the DADA2 pipeline reported at https://benjjneb.github.io/dada2/tutorial.html (Callahan et al., 2016). PCR primers were removed with cutadapt (Martin, 2011) with default settings. Sequences were discarded if the software did not detect one or both primers (-discarduntrimmed option). To ensure that sequences were paired after the trimming process the '-pair-filter = any' option was used. Sequences were then filtered using the 'filterAndTrim' function of DADA2 with a maximum error rate of 2 and a fixed length of 270 and $200 \mathrm{bp}$ for forward and reverse reads, respectively. Trimmed sequences were used for error rate estimation (the 'learnErrors' function with default parameters). Finally, sequences were denoised and merged, and variants were inferred using the DADA2 algorithm. Taxonomic annotation was performed after chimera removal using DECIPHER package (Murali et al., 2018) (version 2.0) with the Silva training set 132 (Quast et al., 2013). Tables produced by the DADA2 pipeline were imported into phyloseq (through the phyloseq $\mathrm{R}$ package version 1.22.3), ASVs assigned to chloroplasts and mitochondria have been excluded, and bacterial communities of the three compartments were analyzed.

\section{Count and Isolation of Cultivable Bacteria}

Tissue extracts and soil suspensions were diluted $\left(10^{-1}, 10^{-3}\right.$, $10^{-5}, 10^{-7}$ ) and $100 \mu \mathrm{l}$ of each dilution were plated on tryptic soy agar (TSA) medium (Bio-Rad) in triplicate. Plates were incubated at $30^{\circ} \mathrm{C}$ and the $\mathrm{CFU}$ (colony forming units) were counted after 48 h. For each compartment about 25 different colonies were randomly chosen; then, they were streaked on TSA medium and grown at $30^{\circ} \mathrm{C}$ for $48 \mathrm{~h}$.

\section{Bacterial Strains and Growth Conditions}

The bacterial collection is represented by a panel of 97 isolates from different compartments of $O$. vulgare L. plants (24 isolates from flower compartment, 24 from leaf, 25 from stem and 24 from bulk soil). Isolates are referred to as OV followed by F, L, $\mathrm{S}$ or $\mathrm{T}$ for flower, leaf, stem and bulk soil districts, respectively, and numerated. Bacterial isolates were grown on TSA medium for $48 \mathrm{~h}$ at $30^{\circ} \mathrm{C}$.

\section{Random Amplified Polymorphic DNA Analysis}

Cell lysates were prepared by processing a single isolated colony resuspended in $20 \mu \mathrm{l}$ of sterile $\mathrm{dH}_{2} \mathrm{O}$, by thermal lysis $\left(95^{\circ} \mathrm{C}\right.$ for $10 \mathrm{~min}$ ), followed by cooling on ice for $5 \mathrm{~min}$. RAPD profiles of the bacterial isolates were obtained using the primer 1253 (Table 1). The reaction mix was performed in a $25 \mu \mathrm{l}$-volume with $1 \times$ DreamTaq Buffer, $200 \mu \mathrm{M}$ dNTPs, $500 \mathrm{ng}$ of primer 1253, 1 U of DreamTaq DNA Polymerase (Thermo Scientific) and $2 \mu \mathrm{l}$ of thermal lysate used as template. The PCR cycling adopted was set up in a Bio-Rad T100 thermal cycler as follows: $90^{\circ} \mathrm{C}$ for $1 \mathrm{~min}, 95^{\circ} \mathrm{C}$ for $95 \mathrm{~s}$ followed by 45 cycles of $95^{\circ} \mathrm{C}$ for $30 \mathrm{~s}$, $36^{\circ} \mathrm{C}$ for $1 \mathrm{~min}, 75^{\circ} \mathrm{C}$ for $2 \mathrm{~min}$, then $75^{\circ} \mathrm{C}$ for $10 \mathrm{~min}$ and finally $60^{\circ} \mathrm{C}$ for $10 \mathrm{~min}$. Amplicons were visualized through a $2 \% \mathrm{w} / \mathrm{v}$ 
TABLE 1 | Primers used in this work.

\begin{tabular}{llll}
\hline Primer & Sequence $\left(\mathbf{5}^{\prime} \mathbf{>} \mathbf{3}^{\prime}\right)$ & Amplicon & References \\
\hline P0 & GAGAGTTTGATCCTGGCTCAG & 16S rDNA & $\begin{array}{l}\text { Di Cello and Fani, } \\
1996\end{array}$ \\
P6 & CTACGGCTACCTTGTTACGA & & \\
1253 & GTTCCGCCC & RAPDs & Mori et al., 1999 \\
\hline
\end{tabular}

agarose gel electrophoresis. The assignment of different isolates to the same haplotype group was determined on the basis of the fingerprint pattern of each RAPD product, comparing them for the presence/absence of bands. For haplotypes represented by more than one isolate derived from the same compartment, a single bacterial isolate was randomly chosen as representative strain for that RAPD haplotype.

\section{S rRNA Gene Sequences}

For each recognized RAPD haplotype, the $16 \mathrm{~S}$ rRNA coding gene sequence was used for the taxonomic affiliation of the bacterial isolates. Amplification of $16 \mathrm{~S}$ rDNA gene was obtained in a total volume of $20 \mu \mathrm{l}$, containing $1 \times$ DreamTaq Buffer, $250 \mu \mathrm{M}$ dNTPs, $0.6 \mu \mathrm{M}$ of primers P0 and P6 (Table 1), $2 \mathrm{U}$ of Dream Taq DNA Polymerase (Thermo Scientific), and $1 \mu \mathrm{l}$ of thermal lysate used as template. Samples were incubated for $3 \mathrm{~min}$ in a thermal cycler (Bio-Rad T100) at $95^{\circ} \mathrm{C}$, then amplification was achieved with 30 cycles of $30 \mathrm{~s}$ at $95^{\circ} \mathrm{C}, 30 \mathrm{~s}$ at $50^{\circ} \mathrm{C}$, and $1 \mathrm{~min}$ at $72^{\circ} \mathrm{C}$, with a final extension at $72^{\circ} \mathrm{C}$ for $10 \mathrm{~min}$. Amplicons were analyzed through a $0.8 \% \mathrm{w} / \mathrm{v}$ agarose gel electrophoresis. Sequencing of the $16 \mathrm{~S}$ rDNA amplicons was performed by the Microsynth Seqlab (Germany). Each sequence was submitted to Gene Bank and the accession numbers from No MN811044 to No MN811099 (Supplementary Table S1).

\section{Phylogenetic Tree Analysis}

Taxonomic affiliation of the strains was determined through the analysis of $16 \mathrm{~S}$ rRNA gene sequences obtained. They were aligned to those of type strains retrieved from the Ribosomal Database Project (RDP) (Cole et al., 2014) using BioEdit (Hall, 1999). The obtained alignment was then used to build a phylogenetic tree through MEGA X (Kumar et al., 2018) for each genus, applying the Neighbor-Joining algorithm with a 1000-bootstrap resampling.

\section{Antibiotics Resistance Profile of Cultivable Bacteria Associated to O. vulgare}

Evaluation of antibiotic resistance was performed by streaking each strain on TSA medium containing different concentration of selected antibiotics, according to Mengoni et al. (2014). The chosen antibiotics were chloramphenicol, ciprofloxacin, rifampicin, streptomycin, kanamycin, and tetracycline (Table 2). After growing on TSA medium for $48 \mathrm{~h}$ at $30^{\circ} \mathrm{C}$, a colony of each strain was suspended in $100 \mu \mathrm{l}$ saline solution $(0.9 \% \mathrm{w} / \mathrm{v} \mathrm{NaCl})$, streaked on TSA medium supplemented with different antibiotics and then incubated at $30^{\circ} \mathrm{C}$ for $48 \mathrm{~h}$. The following antibiotic
TABLE 2 | Classes and targets of the antibiotics used in this work.

\begin{tabular}{lll}
\hline Antibiotic & Class & Target \\
\hline Chloramphenicol & Phenicols & \\
Ciprofloxacin & Fluoroquinolones & Ribosome \\
Kanamycin & Aminoglycosides & Topoisomerases \\
Rifampicin & Ansamycins & Ribosome \\
Streptomycin & Aminoglycosides & RNA polymerase \\
Tetracycline & Tetracyclines & Ribosome \\
\hline
\end{tabular}

concentrations $(\mu \mathrm{g} / \mathrm{ml})$ were tested: chloramphenicol (1-2.5-510-25-50); ciprofloxacin, streptomycin and kanamycin (0.5-12.5-5-10-50); rifampicin (5-10-25-50-100); tetracycline (0.5-1.252.5-5-12.5-25). The different growth levels were indicated as follows: complete growth $(++)$, strong $(+)$, weak $(+-)$, very weak $(+-)$, and absence of growth $(-)$, and MIC (Minimal Inhibiting Concentration) values were identified.

\section{Analysis of Antagonistic Interactions Through Cross-Streaking}

Bacterial strains isolated from each compartment of $O$. vulgare plants were tested for cross antagonism, using representatives of each RAPD haplotype. Antagonistic interactions were assayed between each compartment of $O$. vulgare within-niche and crossniche. Tester strains were firstly streaked across one half of a TSA plate and grown at $30^{\circ} \mathrm{C}$ for $48 \mathrm{~h}$ in order to allow the possible production of antimicrobial compounds. Target strains were then streaked perpendicularly to the tester strain and plates were incubated at $30^{\circ} \mathrm{C}$ for further $48 \mathrm{~h}$. Additionally, target strains were grown at $30^{\circ} \mathrm{C}$ for $48 \mathrm{~h}$ in the absence of the tester, as growth control. The antagonistic effect was evaluated as the absence or reduction of the target strains growth compared to their growth in the absence of the tester strain. The different inhibition levels were indicated with numbers from 0 to 3 as follows: complete ( 3 , red), strong (2, orange), weak (1, salmon), and absence (0, white) of inhibition (Maida et al., 2016).

\section{Inhibition of Human Pathogens by O. vulgare Associated Bacteria}

A panel of selected strains of $O$. vulgare for which high antagonistic interactions were evidenced, was tested against 46 pathogenic strains: 10 for Staphylococcus aureus, 10 for Coagulase-negative staphylococci, 10 for Pseudomonas aeruginosa, 6 for Klebsiella pneumoniae characterized by their resistance to multiple antibiotics (as reported in Table 3), and 10 of a Burkholderia cepacia complex (BCC) collection, MDR BCC bacteria able to resist to different antibiotic classes (e.g., polymyxins, most of beta-lactams and aminoglycosides) (Saiman et al., 2003). The bacterial strains were isolated from different sources (hospital devices, foods, patients, healthy subjects, environment), as shown in Table 3. As reported in the BCCM/LMG bacteria collection database, origins of the BCC strains classified as environmental are the following: LMG1222, onion; LMG17588, soil; LMG19182, pea rhizosphere; 
TABLE 3 | Pathogenic strains used in the study and related antibiotic resistance profiling.

\begin{tabular}{|c|c|c|c|}
\hline Pathogens & Strain code & Origin & $\begin{array}{l}\text { Antibiotic resistance } \\
\text { profiling }\end{array}$ \\
\hline \multirow[t]{10}{*}{ S. aureus } & ATCC 25923 & - & $\mathrm{P}, \mathrm{NA}$ \\
\hline & 2668 & $\mathrm{~F}$ & AMP, P, DA, TE, E, K, NA \\
\hline & 2749 & HS & VA, TEC, DAP \\
\hline & 3709 & $\mathrm{~F}$ & $\mathrm{DA}, \mathrm{TE}, \mathrm{E}, \mathrm{K}, \mathrm{NA}$ \\
\hline & 3710 & & $\mathrm{DA}, \mathrm{TE}, \mathrm{E}, \mathrm{K}, \mathrm{NA}$ \\
\hline & 4070 & & P, DA, TE, E, CIP, LEV, DAP \\
\hline & 4168 & & AMP, P, DA, SXT, TE, NA \\
\hline & 4302 & & P, FOX, SXT, DAP \\
\hline & 4691 & $\mathrm{P}$ & P, FOX, E, CN, CIP, LEV, DAP \\
\hline & 4708 & & P, FOX, CN, VA, DAP \\
\hline \multirow[t]{4}{*}{ S. haemolyticus } & 5284 & $H D$ & $\mathrm{P}, \mathrm{TE}, \mathrm{E}, \mathrm{CN}, \mathrm{FD}$ \\
\hline & 5285 & & E, CN, CIP, LEV, FD \\
\hline & 5383 & & P, FOX, TE, E, CN \\
\hline & 5396 & $\mathrm{HS}$ & P, FOX, SXT, CN, FD \\
\hline \multirow[t]{6}{*}{ S. epidermidis } & 5318 & $\mathrm{HS}$ & $\mathrm{P}, \mathrm{E}, \mathrm{CN}, \mathrm{FD}$ \\
\hline & 5321 & & $P, E, C N, A K, F D$ \\
\hline & 5323 & & $P, T E, T I G, E, C N$ \\
\hline & 5377 & $H D$ & $P, T E, E, T E C$ \\
\hline & 5403 & HS & $P, E, T I G, T E$ \\
\hline & 5419 & $\mathrm{~F}$ & FOX, DA, CIP, LEV, SXT, TIG \\
\hline \multirow[t]{10}{*}{$P$. aeruginosa } & ATCC 27853 & - & FOX, K \\
\hline & 4177 & $H D$ & $\begin{array}{l}\text { AK, TOB, CIP, LEV, CAZ, FEP, } \\
\text { MEM, IPM, ATM, PRL, TZP }\end{array}$ \\
\hline & 4189 & & $\begin{array}{l}\text { AK, TOB, CIP, LEV, CAZ, FEP, } \\
\text { MEM, IPM, PRL, TZP }\end{array}$ \\
\hline & 5234 & & $\begin{array}{l}\text { AK, CAZ, ATM, TZP, PRL, FEP, } \\
\text { CN, IPM, MEM, LEV, CIP, TOB }\end{array}$ \\
\hline & 5245 & & $\begin{array}{l}\text { CAZ, ATM, PRL, FEP, CN, LEV, } \\
\text { CIP, IPM, MEM, TOB }\end{array}$ \\
\hline & 5246 & & $\begin{array}{l}\text { CAZ, ATM, TZP, PRL, FEP, CN, } \\
\text { IPM, MEM, LEV, CIP, TOB }\end{array}$ \\
\hline & 5255 & & AK, ATM, CN, FEP, TOB \\
\hline & 5139 & & CIP, CN, FEP, LEV, TOB \\
\hline & 5009 & & $\begin{array}{l}\text { ATM, CAZ, CIP, CN, FEP, IPM, } \\
\text { LEV, MEM, PRL, TOB, TZP }\end{array}$ \\
\hline & 5236 & & $\begin{array}{l}\text { AK, ATM, CAZ, CIP, FEP, IPM, } \\
\text { LEV, MEM, TOB }\end{array}$ \\
\hline \multirow[t]{6}{*}{ K. pneumoniae } & ATCC 700603 & - & CAZ, AMP, ATM, PRL, TE \\
\hline & 4409 & $\mathrm{P}$ & $\begin{array}{l}\text { AK, AMX, FEP, CTX, CAZ, CIP, } \\
\text { ETP, IPM, MEM, TZP, SXT, FFL, } \\
\text { CL, TIG }\end{array}$ \\
\hline & 4412 & & $\begin{array}{l}\text { AMX, FEP, CTX, CAZ, CIP, ETP, } \\
\text { IPM, MEM, TZP, SXT, FFL, TIG }\end{array}$ \\
\hline & 4417 & & $\begin{array}{l}\text { AK, AMX, FEP, CTX, CAZ, CIP, } \\
\text { ETP, IPM, MEM, TZP, SXT, FFL, } \\
\text { CL, TIG }\end{array}$ \\
\hline & 4420 & & $\begin{array}{l}\text { AK, AMX, FEP, CTX, CAZ, CIP, } \\
\text { IPM, MEM, TZP, SXT, FFL, CL, } \\
\text { CN }\end{array}$ \\
\hline & 4422 & & $\begin{array}{l}\text { AK, AMX, FEP, CTX, CAZ, CIP, } \\
\text { ETP, IPM, MEM, TZP, SXT, FFL }\end{array}$ \\
\hline B. cepacia & FCF3 & $\mathrm{CF}$ & \\
\hline B. cenocepacia & FCF23 & & \\
\hline B. multivorans & LMG13010 & & \\
\hline
\end{tabular}

(Continuted)
TABLE 3 | Continued

\begin{tabular}{|c|c|c|c|}
\hline Pathogens & Strain code & Origin & $\begin{array}{l}\text { Antibiotic resistance } \\
\text { profiling }\end{array}$ \\
\hline B. ambifaria & LMG_16656 & & \\
\hline B. cenocepacia & LMG_21462 & & \\
\hline B. cenocepacia & LMG_24506 & & \\
\hline B. cepacia & LMG_1222 & $E$ & \\
\hline B. multivorans & LMG_17588 & & \\
\hline B. ambifaria & LMG_19182 & & \\
\hline B. cenocepacia & LMG_19230 & & \\
\hline
\end{tabular}

$F=$ food, $H D=$ hospital devices, $H S=$ healthy subjects, $P=$ patients, $C F=$ Cystic Fibrosis, $E=$ environment. Amikacin (AK), Amoxicillin (AMX), Ampicillin (AMP), Aztreonam (ATM), Cefepime (FEP), Cefotaxime (CTX), Cefoxitin (FOX), Ceftazidime $(C A Z)$, Ciprofloxacin (CIP), Clindamycin (DA), Colistin (CL), Daptomycin (DAP), Ertapenem (ETP), Erythromycin (E), Florfenicol (FFL), Fusidic Acid (FD), Gentamicin $(C N)$, Imipenem (IPM), Kanamycin (K), Levofloxacin (LEV), Meropenem (MEM), Nalidixic Acid (NA), Penicillin G (P), Piperacillin (PRL), Piperacillin/Tazobactam (TZP), Sulfamethoxazole/Trimethoprim (SXT), Teicoplanin (TEC), Tetracycline (TE), Tigecycline (TIG), Tobramycin (TOB), Vancomycin (VA).

LMG19230, wheat roots. Each strain was maintained at $-80^{\circ} \mathrm{C}$ under glycerol (25\%, v/v) stock, cultured in Brain Heart Infusion Broth (Thermo Scientific) for $24 \mathrm{~h}$ at $37^{\circ} \mathrm{C}$, then streaked on TSA, and incubated at $37^{\circ} \mathrm{C}$ for $24 \mathrm{~h}$ before the use. The isolated bacterial strains ( $S$. aureus, CoNS, $P$. aeruginosa, K. pneumoniae) were provided from the Applied Microbiology laboratory (Health Sciences Dept., University of Florence, Italy), while the standard bacteria Staphylococcus aureus ATCC 25923, Pseudomonas aeruginosa ATCC 27853 and Klebsiella pneumonia ATCC 700603 were obtained from Thermo Fisher Diagnostics S.p.A. The antimicrobial activity was evaluated through the cross-streak method, as previously described, except for the incubation temperature of target strains: $48 \mathrm{~h}$ at $37^{\circ} \mathrm{C}$ for CoNS (Coagulase-negative staphylococci) and $24 \mathrm{~h}$ at $37^{\circ} \mathrm{C}$ for all the other pathogens. The degree of antagonistic effect was evaluated by measuring the inhibition or reduction zone and the results were presented with numbers from 0 to 3 as previously described. The sum of numbers of each bacterial strain represents the total score of inhibition (TSI) ability against human pathogens. TSI was scored as absence of activity (TSI $=0$ ), very low activity (TSI $=1-10)$, low activity (TSI $=11-20)$, strong activity (TSI $=21-27)$, and very strong activity $($ TSI $=28-30)$ (Maida et al., 2016).

\section{RESULTS}

\section{Chemical Characterization of the O. vulgare L. Essential Oil and Chemotype Attribution}

The complete composition of the EO hydrodistilled from the analyzed O. vulgare specimen is reported in Supplementary Table S2. Terpene hydrocarbons dominated the composition, since they were detected in a relative amount accounting for over $90 \%$ of the total. Sesquiterpene hydrocarbons, in particular, added up to over $70 \%$ of the total: among them, germacrene D and $\beta$-caryophyllene were the most abundant, exhibiting relative 


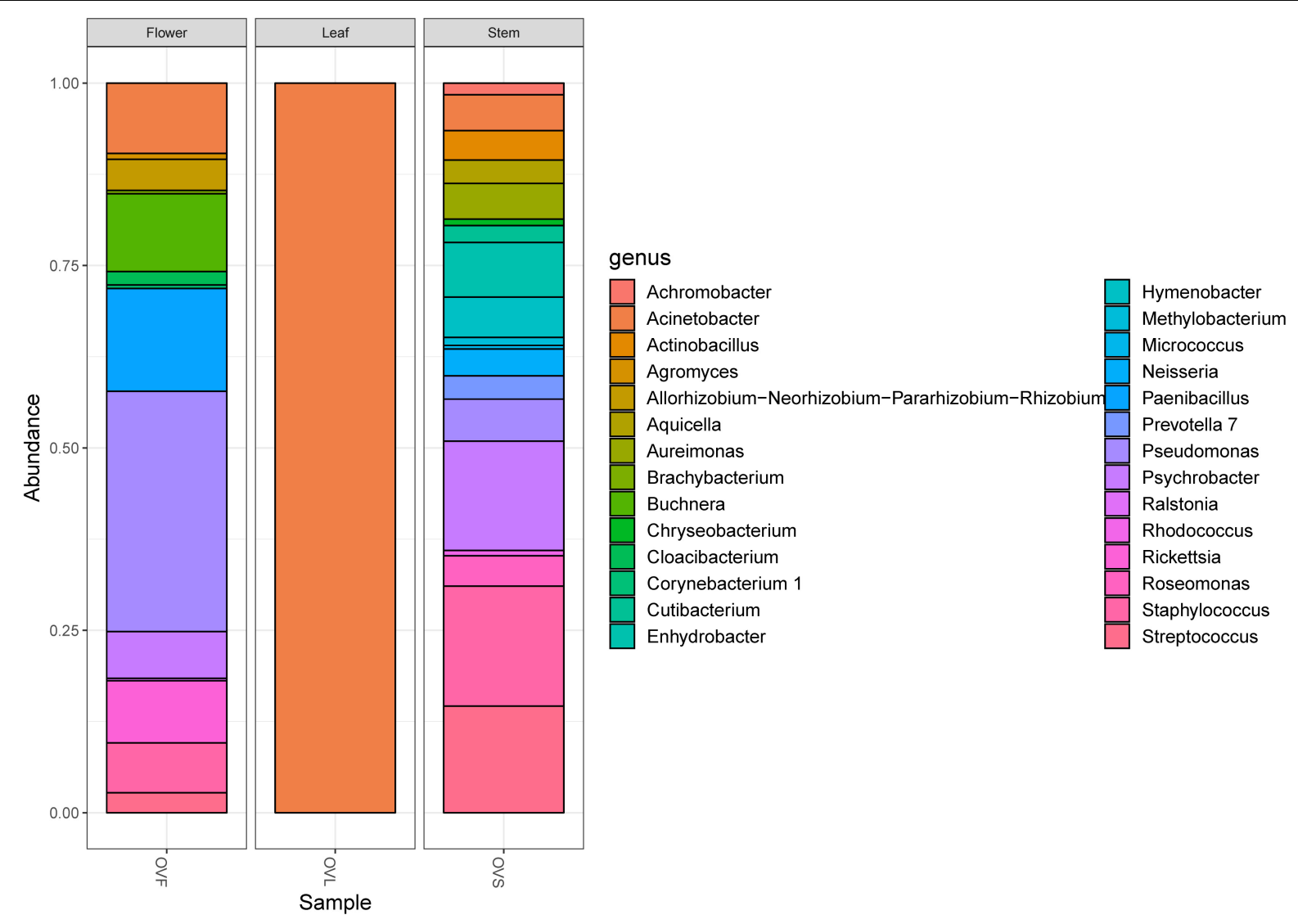

FIGURE 1 | Bar plot showing the relative abundances of bacterial genera in each sample. OVF = flower, OVL = leaf, OVS = stem compartment.

abundances of 29.4 and $19.2 \%$, respectively. The plant was, thus, a germacrene $\mathrm{D} / \beta$-caryophyllene chemotype. The oxygenated terpenes were far less represented, accounting only for the remaining 8.6\%: among them, only 4-terpineol, caryophyllene oxide and spathulenol exhibited relative concentrations higher than $1 \%$.

\section{Characterization of the Plant Microbiota}

Bacterial communities of plant samples of the same compartments from which the $\mathrm{EO}$ of $\mathrm{O}$. vulgare plants was obtained (i.e., flower, leaf, and stem) were examined through NGS. Quality filtering steps obtained a total of 53 ASVs, and representative sequences for each ASV were classified into 28 genera belonging to 4 phyla according to the Silva database, with a different distribution between leaves (with only one genus, Acinetobacter, found) and the other two compartments. The majority of the ASVs (62.26\%) belong to Proteobacteria phylum, followed by Firmicutes (15.09\%), Actinobacteria (11.32\%), and Bacteroidetes (11.32\%). Data obtained are shown in Figure 1.

\section{Isolation of Cultivable Bacteria}

Bacteria extracted from flower, leaf, stem of $O$. vulgare plants and bulk soil were plated as described in Materials and Methods. Data obtained revealed that the highest bacterial titers were detected in the soil $\left(5.1 \times 10^{5}\right)$, while the lowest $\mathrm{CFU} / \mathrm{g}$ value was represented by the leaves $\left(7 \times 10^{2}\right)$; flower and stem compartments had $2.16 \times 10^{5}$ and $8.5 \times 10^{3} \mathrm{CFU} / \mathrm{g}$, respectively.

\section{Strain-Level Profiling of Isolates}

To investigate the structure of the culturable microbiota and to define the haplotypes (i.e., individual genotypes) present, a RAPD analysis was performed assuming that isolates sharing the same RAPD fingerprinting correspond to the same strain (Chiellini et al., 2014 and references therein): a total of 62 different RAPD haplotypes was identified, corresponding to 62 different bacterial strains. The distribution of the RAPD haplotypes within the different compartments is shown in Supplementary Table S3. The highest number of haplotypes was detected in the stem compartment (19 haplotypes out of 25 bacterial isolates), while the soil compartment exhibited the lowest number of haplotypes (12 haplotypes out of 24 isolates) as shown in Table 4 . Notably, a very low number of haplotypes was shared between the different compartments: indeed, only 2 strains were shared by the leaf and stem compartments.

\section{Taxonomic Assignment of Strains}

The taxonomic identification of strains from RAPD haplotyping by $16 \mathrm{~S}$ rRNA gene sequencing is summarized in Figure 2 . 
TABLE 4 | Distribution of bacterial haplotypes, species, and genera detected in the four districts of O. vulgare plant.

\begin{tabular}{|c|c|c|c|c|c|c|c|}
\hline & & Flower (OVF) & Leaf (OVL) & Stem (OVS) & Soil (OVT) & Total & $\%$ \\
\hline N. of isolates & & 24 & 24 & 25 & 24 & 97 & / \\
\hline N. of haplotypes & & 16 & 17 & 19 & 12 & 62 & / \\
\hline N. of species & & 11 & 13 & 13 & 9 & 32 & / \\
\hline N. of genera & & 8 & 8 & 8 & 6 & 19 & / \\
\hline \multirow[t]{4}{*}{ N. of shared haplotypes } & Flower & - & 0 & 0 & 0 & 2 & 3.2 \\
\hline & Leaf & - & - & 2 & 0 & & \\
\hline & Stem & - & - & - & 0 & & \\
\hline & Soil & - & - & - & - & & \\
\hline \multirow[t]{4}{*}{ N. of shared species } & Flower & - & 1 & 3 & 2 & 9 & 28 \\
\hline & Leaf & - & - & 5 & 4 & & \\
\hline & Stem & - & - & - & 5 & & \\
\hline & Soil & - & - & - & - & & \\
\hline \multirow[t]{4}{*}{ N. of shared genera } & Flower & - & 2 & 3 & 1 & 7 & 37 \\
\hline & Leaf & - & - & 5 & 0 & & \\
\hline & Stem & - & - & - & 1 & & \\
\hline & Soil & - & - & - & - & & \\
\hline
\end{tabular}

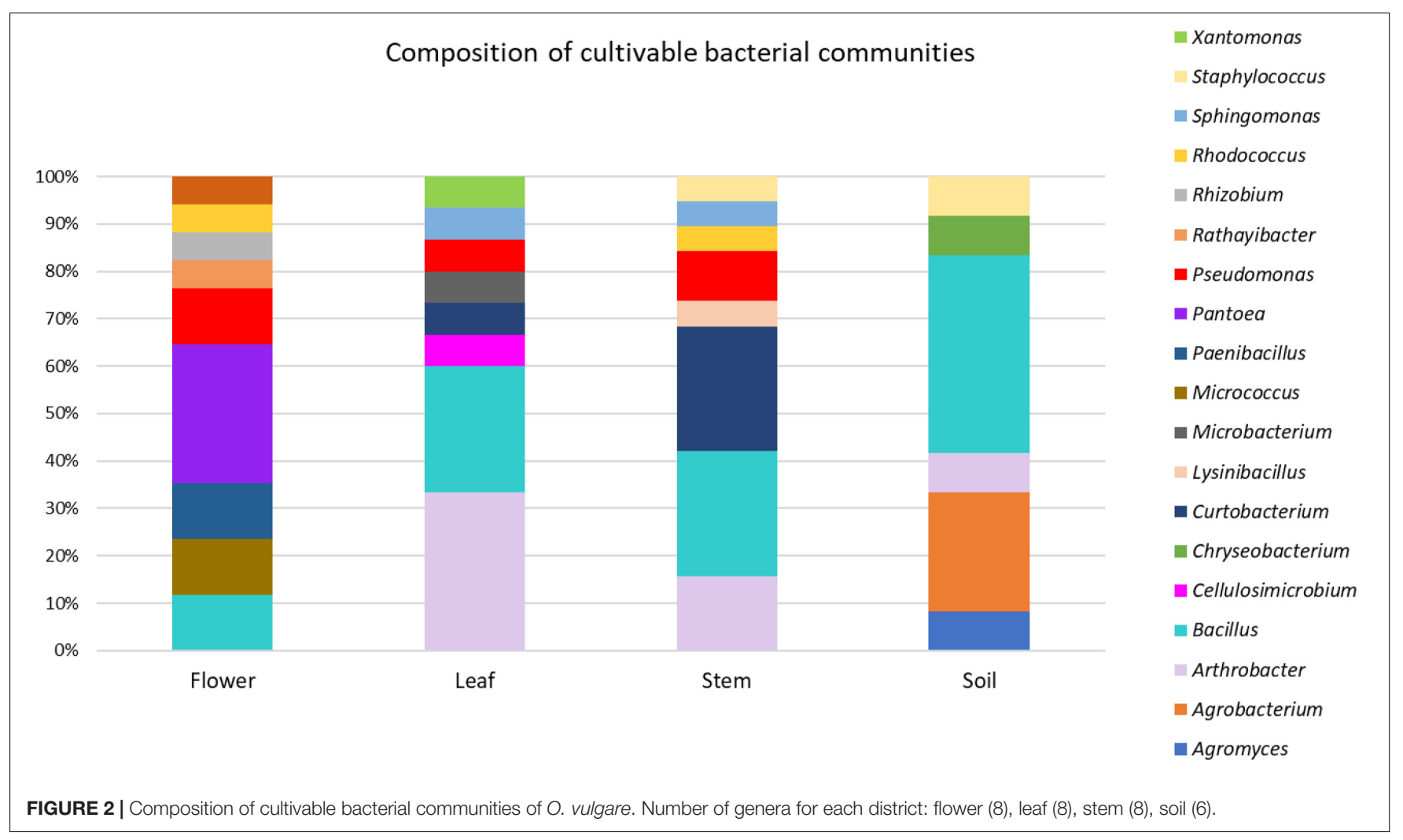

This analysis revealed that: (i) strains were affiliated to 19 different bacterial genera (42.1\% Gram negative, 57.9\% Gram positive); (ii) the majority of the $16 \mathrm{~S}$ rDNA gene sequences was affiliated to the genus Bacillus (28.12\%); (iii) Arthrobacter was the second most highly represented genus (14.06\%); (iv) seven genera (Pseudomonas, Sphyngomonas, Curtobacterium, Arthrobacter, Bacillus, Staphylococcus, Rhodococcus) were shared among compartments, however just the genus Bacillus was shared by all the four districts. Moreover, a total of 12 genera were represented in only a single district, such as Pantoea, Rhizobium, Paenibacillus, Micrococcus, and Rathayibacter, which were detected only in the flower compartment (Figure 3).

For each genus a $16 \mathrm{~S}$ rRNA gene phylogenetic tree was constructed as described in Materials and Methods. The analysis of the obtained phylogenetic trees (shown in Supplementary Material from Figures S1 to Figure S18) allowed to affiliate the 62 strains to 32 (possible) different species. The $28.1 \%$ of species resulted to be shared by the flower, leaf, stem, and 


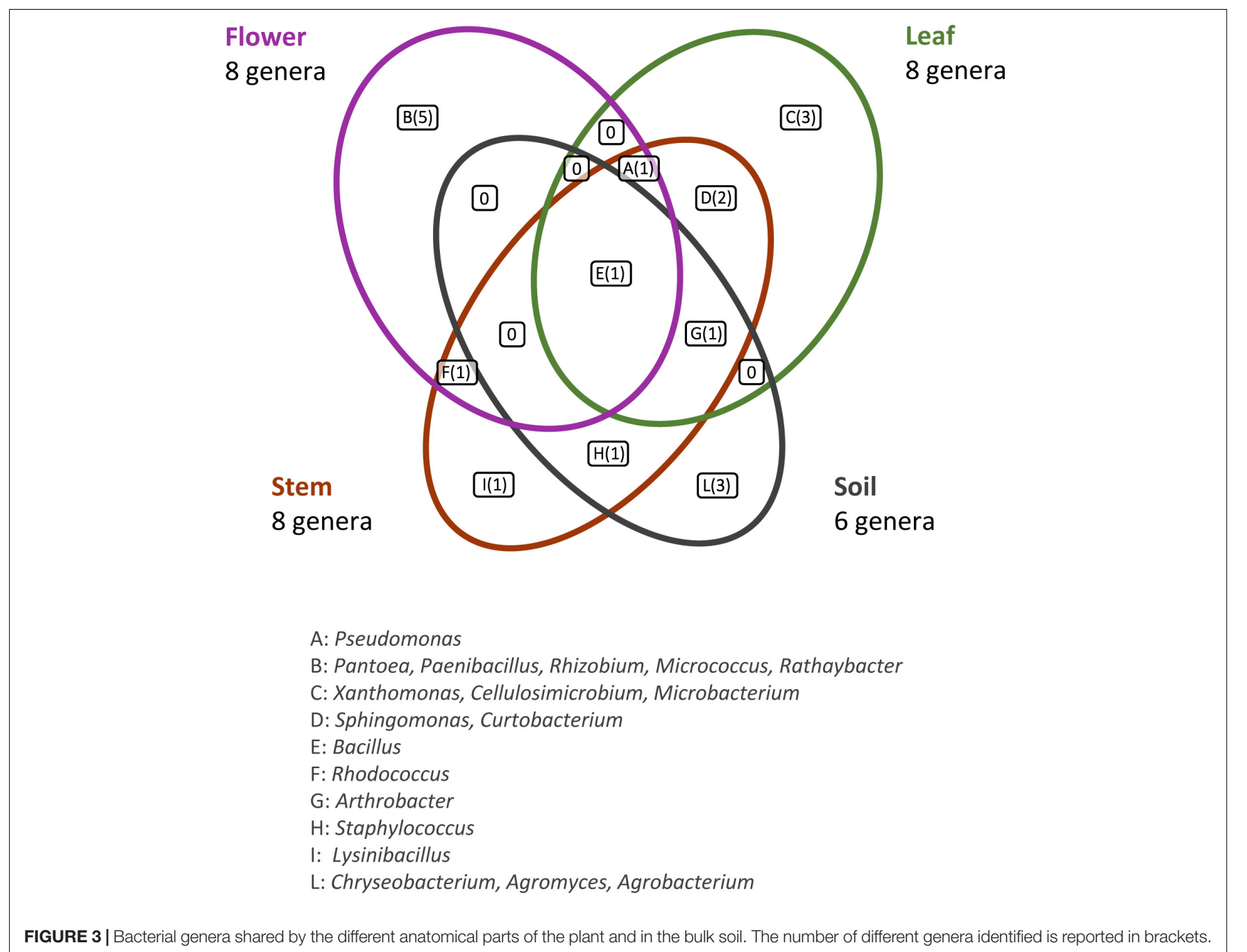

soil compartments. Only one species (i.e., Bacillus megaterium) resulted to be shared between all the four districts. The compartments with the highest number of species were leaf and stem districts (for both of them 13 different species were identified).

\section{Antibiotics Resistance Profiles}

The antibiotic resistance profiles of bacteria associated to the four $O$. vulgare compartments were investigated, as described in Materials and Methods. The Minimal Inhibitory Concentration (MIC) of each antibiotic was evaluated and the values are reported in Table 5. The $45.16 \%$ of the $O$. vulgare associated bacteria showed MIC value for the antibiotic streptomycin $<2.5 \mu \mathrm{g} / \mathrm{ml}$, and the $37.09 \%$ showed a very high MIC level $(50 \mu \mathrm{g} / \mathrm{ml})$. Regarding the antibiotic kanamycin the 41.93\% revealed MIC value at the maximum concentration used or more. In particular, a very high tolerance to streptomycin and kanamycin, even to the highest concentrations used (MIC values $>50 \mu \mathrm{g} / \mathrm{ml}$ ), was revealed by some strains associated to the bulk soil and leaves. MIC value for tetracycline was evaluated at low concentrations $(<2.5 \mu \mathrm{g} / \mathrm{ml})$ for the majority of the strains $(83.87 \%)$. Some strains showed the capacity to grow in presence of low concentrations of chloramphenicol and ciprofloxacin, and only a few strains (12 out of 62) demonstrated to tolerate the lowest concentrations $(5 \mu \mathrm{g} / \mathrm{ml})$ of rifampicin as well. Moreover, the $89.40 \%$ of the bacteria associated to the stem were almost totally inhibited by streptomycin, even at the lowest concentration. The different antibiotic resistance profiles seemed to not correlate with the species affiliation and/or the districts from whom bacteria were isolated. Nonetheless, just in case of streptomycin resistance of Arthrobacter strains, those isolated from the stem were much more sensitive in comparison to those ones associated to the leaves. Overall, strains associated to the bulk soil resulted tolerant to the great majority of the antibiotics tested, even at the highest concentrations used.

\section{Antagonistic Interaction Between O. vulgare Associated Bacteria}

Antagonistic interactions, at both inter- and intra-compartment level, were tested through cross-streak test, as described in 
TABLE 5 | Antibiotic resistance assay of O. vulgare associated bacteria.

\begin{tabular}{|c|c|c|c|c|c|c|c|c|}
\hline \multirow[t]{2}{*}{ Compartment } & \multirow[t]{2}{*}{ Strain } & \multirow[t]{2}{*}{ Taxonomy } & \multicolumn{6}{|c|}{ MIC $(\mu \mathrm{g} / \mathrm{ml})$} \\
\hline & & & Str. & Tet. & Cip. & Kan. & Chl. & Rif. \\
\hline $\mathrm{T}$ & OVT1 & Agrobacterium & $>50$ & 2.5 & $<0.5$ & 50 & 25 & 10 \\
\hline $\mathrm{T}$ & OVT8 & Agrobacterium & $>50$ & 2.5 & $<0.5$ & 50 & 25 & 10 \\
\hline $\mathrm{T}$ & OVT17 & Agrobacterium & $>50$ & 2.5 & $<0.5$ & 50 & 25 & 10 \\
\hline $\mathrm{T}$ & OVT2 & Agromyces & $>50$ & $>25$ & 50 & $>50$ & 10 & $<5$ \\
\hline S & OVS8 & Arthrobacter & $<0.5$ & $<0.5$ & 5 & 50 & $<1$ & $<5$ \\
\hline S & OVS18 & Arthrobacter & $<0.5$ & $<0.5$ & 5 & $>50$ & $<1$ & $<5$ \\
\hline S & OVS23 & Arthrobacter & $<0.5$ & 1.25 & 2.5 & 50 & $<1$ & $<5$ \\
\hline$L$ & OVL1 & Arthrobacter & $>50$ & $<0.5$ & 10 & $>50$ & $<1$ & $<5$ \\
\hline$L$ & OVL3 & Arthrobacter & 50 & $<0.5$ & 5 & $>50$ & $<1$ & $<5$ \\
\hline$L$ & OVL4 & Arthrobacter & 50 & $<0.5$ & 2.5 & $>50$ & $<1$ & $<5$ \\
\hline $\mathrm{L}$ & OVL20 & Arthrobacter & 50 & $<0.5$ & 5 & $>50$ & $<1$ & $<5$ \\
\hline $\mathrm{L}$ & OVL22 & Arthrobacter & 50 & $<0.5$ & 5 & $>50$ & $<1$ & $<5$ \\
\hline $\mathrm{T}$ & OVT23 & Arthrobacter & 50 & $<0.5$ & 5 & $>50$ & 2.5 & $<5$ \\
\hline$L$ & OVL7 & Bacillus & $<0.5$ & $<0.5$ & $<0.5$ & $<0.5$ & 2.5 & $<5$ \\
\hline $\mathrm{L}$ & OVL8 & Bacillus & 5.0 & $<0.5$ & $<0.5$ & 1 & 5 & $<5$ \\
\hline S & OVS6 & Bacillus & $<0.5$ & $<0.5$ & $<0.5$ & $<0.5$ & 10 & $<5$ \\
\hline S & OVS10 & Bacillus & $<0.5$ & 2.5 & $<0.5$ & $<0.5$ & 2.5 & $<5$ \\
\hline S & OVS21 & Bacillus & $<0.5$ & 2.5 & $<0.5$ & $<0.5$ & 2.5 & $<5$ \\
\hline $\mathrm{F}$ & OVF22 & Bacillus & 2.5 & 2.5 & $<0.5$ & $<0.5$ & $<1$ & $<5$ \\
\hline$L$ & OVL9 & Bacillus & 2.5 & 1.25 & $<0.5$ & 1 & $<1$ & $<5$ \\
\hline S & OVS26 & Bacillus & 2.5 & 1.25 & $<0.5$ & 2.5 & 2.5 & $<5$ \\
\hline $\mathrm{T}$ & OVT16 & Bacillus & 2.5 & 2.5 & $<0.5$ & $<0.5$ & 10 & $<5$ \\
\hline $\mathrm{T}$ & OVT24 & Bacillus & 2.5 & 1.25 & $<0.5$ & $<0.5$ & 2.5 & $<5$ \\
\hline$L$ & OVL12 & Bacillus & 10 & 5 & $<0.5$ & 1 & $<1$ & $<5$ \\
\hline $\mathrm{T}$ & OVT5 & Bacillus & 10 & $<0.5$ & $<0.5$ & 2.5 & 2.5 & $<5$ \\
\hline $\mathrm{F}$ & OVF21 & Bacillus & 50 & 2.5 & $<0.5$ & 10 & 2.5 & $<5$ \\
\hline S & OVS24 & Bacillus & $>50$ & $<0.5$ & $<0.5$ & 5 & 2.5 & $<5$ \\
\hline $\mathrm{T}$ & OVT10 & Bacillus & 50 & $<0.5$ & $<0.5$ & 5 & 2.5 & $<5$ \\
\hline $\mathrm{T}$ & OVT20 & Bacillus & 50 & 5 & $<0.5$ & 10 & 2.5 & $<5$ \\
\hline$L$ & OVL16 & Cellulosimicrobium & $>50$ & 12.5 & 50 & $>50$ & 10 & $<5$ \\
\hline $\mathrm{T}$ & OVT9 & Chryseobacterium & $>50$ & $>25$ & 1 & $>50$ & $>50$ & $<5$ \\
\hline S & OVS2 & Curtobacterium & $<0.5$ & 2.5 & 2.5 & $>50$ & 2.5 & $<5$ \\
\hline S & OVS11 & Curtobacterium & $<0.5$ & 12.5 & 50 & $>50$ & $<1$ & $<5$ \\
\hline S & OVS12 & Curtobacterium & $<0.5$ & 12.5 & 50 & $>50$ & $<1$ & $<5$ \\
\hline S & OVS13 & Curtobacterium & $<0.5$ & 2.5 & 50 & 50 & $<1$ & $<5$ \\
\hline S & OVS15 & Curtobacterium & $<0.5$ & 12.5 & 50 & $>50$ & $<1$ & $<5$ \\
\hline$L$ & OVL10 & Curtobacterium & 2.5 & 1.25 & $<0.5$ & 10 & $<1$ & $<5$ \\
\hline S & OVS27 & Lysinibacillus & $>50$ & 1.25 & 2.5 & 1 & 2.5 & 10 \\
\hline $\mathrm{L}$ & OVL14 & Microbacterium & 5 & 12.5 & 5 & $>50$ & $<1$ & $<5$ \\
\hline $\mathrm{F}$ & OVF19 & Micrococcus & 10 & 1.25 & 5 & 50 & $<1$ & $<5$ \\
\hline$F$ & OVF24 & Micrococcus & $>50$ & 1.25 & 5 & 50 & $<1$ & $<5$ \\
\hline $\mathrm{F}$ & OVF3 & Paenibacillus & 2.5 & $<0.5$ & $<0.5$ & $<0.5$ & 2.5 & 10 \\
\hline$F$ & OVF10 & Paenibacillus & 2.5 & 2.5 & $<0.5$ & $<0.5$ & $<1$ & $<5$ \\
\hline$F$ & OVF2 & Pantoea & 10 & 2.5 & $<0.5$ & 10 & 2.5 & 10 \\
\hline $\mathrm{F}$ & OVF14 & Pantoea & 10 & 2.5 & $<0.5$ & 10 & 2.5 & 10 \\
\hline$F$ & OVF1 & Pantoea & $>50$ & 2.5 & $<0.5$ & 10 & 2.5 & 10 \\
\hline $\mathrm{F}$ & OVF9 & Pantoea & 50 & 2.5 & $<0.5$ & 10 & 2.5 & 10 \\
\hline $\mathrm{F}$ & OVF11 & Pantoea & 50 & 2.5 & $<0.5$ & 5 & 2.5 & 10 \\
\hline $\mathrm{F}$ & OVF4 & Pseudomonas & 5 & 2.5 & $<0.5$ & 2.5 & 25 & $<5$ \\
\hline $\mathrm{L}$ & OVL17 & Pseudomonas & 5 & 2.5 & $<0.5$ & 1 & 25 & $<5$ \\
\hline S & OVs9 & Pseudomonas & $<0.5$ & 2.5 & $<0.5$ & 2.5 & 25 & 10 \\
\hline
\end{tabular}


TABLE 5 | Continued

\begin{tabular}{|c|c|c|c|c|c|c|c|c|}
\hline \multirow[t]{2}{*}{ Compartment } & \multirow[t]{2}{*}{ Strain } & \multirow[t]{2}{*}{ Taxonomy } & \multicolumn{6}{|c|}{ MIC ( $\mu \mathrm{g} / \mathrm{ml})$} \\
\hline & & & Str. & Tet. & Cip. & Kan. & Chl. & Rif. \\
\hline S & OVS14 & Pseudomonas & $<0.5$ & 1.25 & $<0.5$ & $<0.5$ & 25 & 10 \\
\hline $\mathrm{F}$ & OVF7 & Pseudomonas & 2.5 & $<0.5$ & $<0.5$ & $<0.5$ & 2.5 & $<5$ \\
\hline $\mathrm{F}$ & OVF17 & Rathaybacter & 2.5 & $<0.5$ & 2.5 & 10 & $<1$ & $<5$ \\
\hline $\mathrm{F}$ & OVF6 & Rhizobium & 5 & 2.5 & $<0.5$ & 50 & 2.5 & $<5$ \\
\hline S & OVS20 & Rhodococcus & $<0.5$ & 2.5 & $<0.5$ & 10 & $<1$ & $<5$ \\
\hline $\mathrm{F}$ & OVF18 & Rhodococcus & 2.5 & 2.5 & $<0.5$ & 5 & $<1$ & $<5$ \\
\hline S & OVS7 & Sphingomonas & $<0.5$ & $<0.5$ & 1 & $<0.5$ & $<1$ & $<5$ \\
\hline$L$ & OVL6 & Sphingomonas & 50 & $<0.5$ & $<0.5$ & 10 & 2.5 & $<5$ \\
\hline S & OVS22 & Staphylococcus & $<0.5$ & 1.25 & 1 & $>50$ & 2.5 & $<5$ \\
\hline $\mathrm{T}$ & OVT21 & Staphylococcus & 10 & $<0.5$ & $<0.5$ & $>50$ & 2.5 & $<5$ \\
\hline$L$ & OVL18 & Xanthomonas & 50 & 5 & $<0.5$ & 10 & 5 & $<5$ \\
\hline
\end{tabular}

MIC values are reported as $\mu \mathrm{g} / \mathrm{ml}$. Str $=$ Streptomycin, Tet $=$ Tetracycline, Cip = Ciprofloxacin, Kan = Kanamicin, Chl = Chloramphenicol, Rif $=$ Rifampicin. F = flower, $L=$ leaf, $S=$ stem, $T=$ soil compartment.

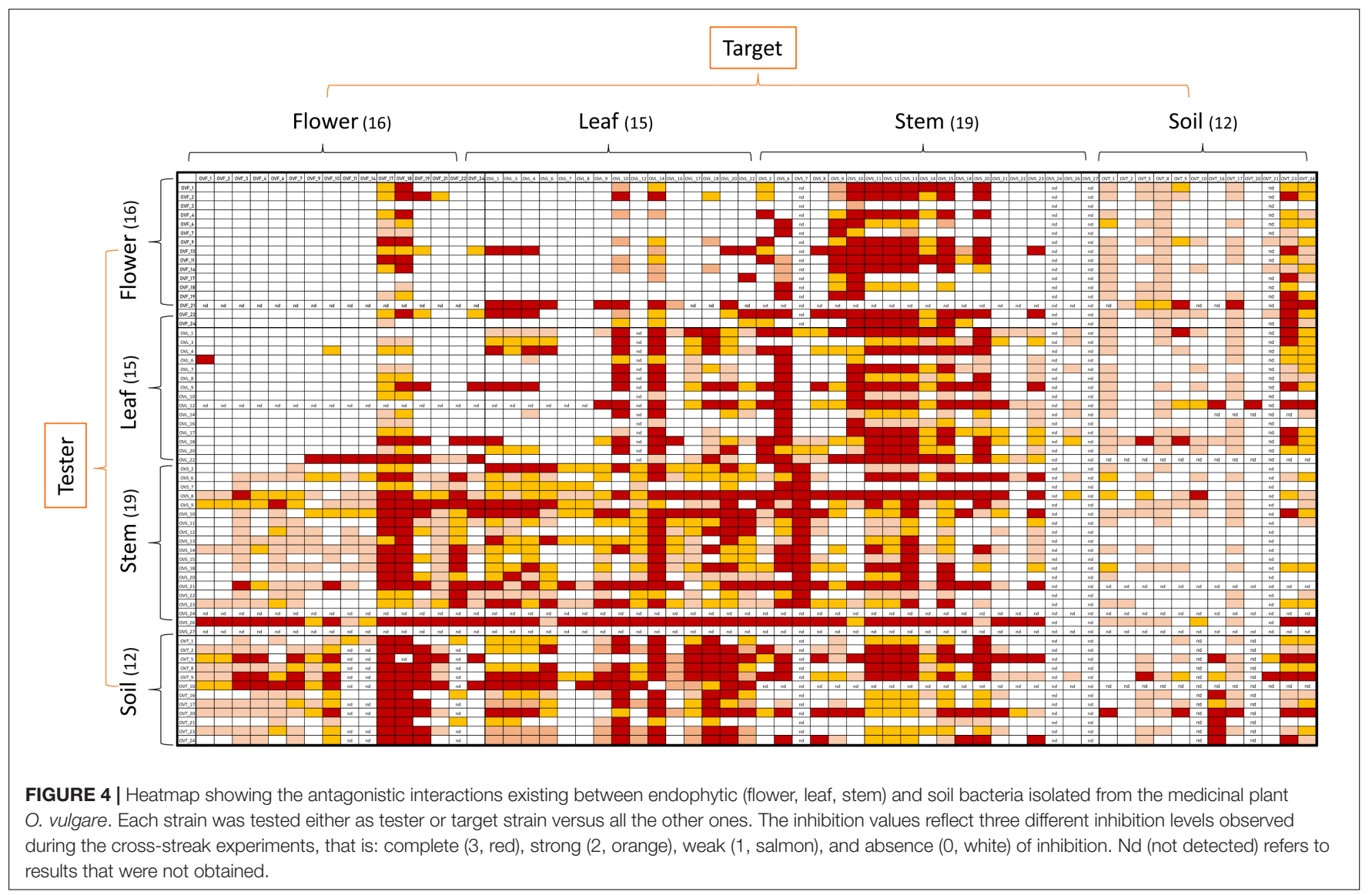

Materials and Methods. To this purpose, each strain was used either as a tester or target. The antagonistic effect was indicated by the absence or reduction of the target strain growth. Data obtained, schematically shown in Figure 4, revealed that: (i) all the tested strains were able to inhibit at least one strain; (ii) soil-associated bacteria revealed a higher capacity to inhibit strains belonging to the other compartments, with those from stem and leaf following; (iii) flowers associated bacteria revealed the lowest capacity to inhibit other strains; (iv) regarding the inhibition sensitivity, the highest values were obtained from stem compartment, with leaf and flower following; and (v) the lowest inhibition sensitivity was revealed by soil-associated bacteria, as they were less inhibited by strains extracted from the different anatomical part of the plants.

Figure 5 shows a representation of the inhibitory pattern among strains from the same and different compartments. In 

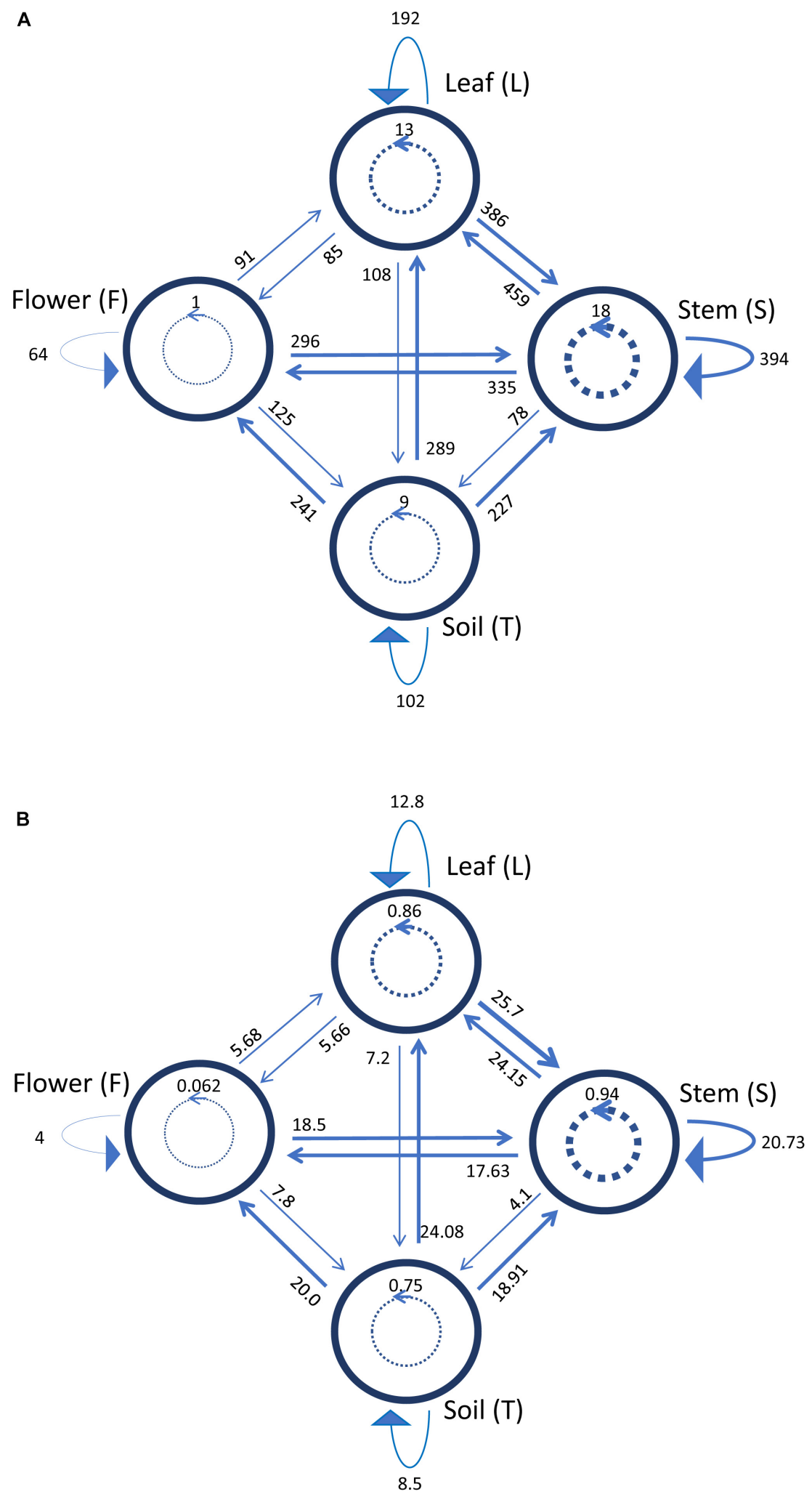

FIGURE 5 | Schematic representation of inhibiting activity of bacterial strains isolated from the medicinal plant $O$. vulgare bulk soil (T), stem (S), leaf (L) and flowers (F). Each node represents a plant compartment whereas numbers represent the sum of the inhibiting scores of the bacteria isolated from those compartments (A) and the inhibition potential of the tester strains calculated as the sum of inhibition scores divided by the tester number (B). Directed links represent inhibition patterns. Dashed links indicate the occurrence and the extent of self-inhibition. 
TABLE 6 | Inhibitory and sensitivity score of the endophytic bacteria associated to the four compartments of $O$. vulgare.

\begin{tabular}{lcc}
\hline Compartment & Inhibitory score & Sensitivity score \\
\hline Soil & 63.41 & 20.25 \\
Stem & 47.62 & 47.99 \\
Leaf & 44.21 & 56.26 \\
Flowers & 32.27 & 46.39 \\
\hline
\end{tabular}

this scheme, each node represents a plant compartment whereas numbers indicate the sum of the inhibiting scores of the bacteria isolated from those compartments and the inhibition potential of tester strains calculated as the sum of inhibition scores divided by the tester number. Inhibition patterns were represented by directed links, while the occurrence and the extent of selfinhibition were reported with dashed links.

The analysis of these results suggested that the bacterial communities from stem and soil were much more able to antagonize the growth of bacteria belonging to the other two compartments (Table 6). The relative degree of inhibitory score and sensitivity score of strains belonging to different compartments are respectively as following: soil $>$ stem $\geq$ leaves $>$ flowers; soil $<$ stem $<$ flowers $<$ leaf. Additionally, stem community showed the highest selfinhibition, whereas flower-associated bacteria revealed the lowest one. So, the different antagonistic activity observed could be, apparently, influenced by the ecological niche inhabited by bacteria.

\section{Inhibition of Human Pathogens by O. vulgare Associated Bacteria}

The endophytic strains (Table 7) exhibiting high antagonistic interactions, have been further tested against human pathogens through cross-streak method, as described in Materials and Methods.

In Figure 6 the antagonistic interactions of $O$. vulgare tester strains against 46 human pathogens are shown.

Interestingly, focusing on the antagonistic activity against BCC, O. vulgare strains were much more able to inhibit the growth of BCC members isolated from CF patients than those of environmental origins (Figure 7). All the flower testers exhibited a low total score of inhibition (TSI $=11-20$ ), the $50 \%$ of leaves tester a strong TSI (TSI $=21-27)$, the $44.5 \%$ of stem tester a strong or very strong TSI (TSI $=21-27,28-30$ ), all the soil testers had a strong or very strong total score of inhibition (TSI $=21-27,28-30)$.

Focusing on the antagonistic activity against $S$. aureus, CoNS, $P$. aeruginosa, K. pneumoniae, among the 23 endophytes strains screened for antimicrobial activity, 11 (47.8\%) showed antagonistic activity against at least one human pathogenic strain (Figure 6). This preliminary test demonstrated that $54.5 \%$ of the inhibitory strains belong to Bacillus genera, $27.3 \%$ to Arthrobacter and the remaining $18.2 \%$ to Paenibacillus and Chryseobacterium genera. Moreover, the interaction among inhibitory endophytes and pathogens gave better antagonistic results for Gram-positive bacteria $(25.9 \%)$ than for Gram-negative bacteria $(3.98 \%)$. The
TABLE 7 | O. vulgare associated bacteria tested against 46 pathogenic strains.

\begin{tabular}{|c|c|c|}
\hline Compartment & Strain code & Taxonomy \\
\hline \multirow[t]{6}{*}{ Flower (F) } & OVF 10 & Paenibacillus \\
\hline & OVF 22 & Bacillus \\
\hline & OVF11 & Pantoea \\
\hline & OVF 6 & Rhizobium \\
\hline & OVF 1 & Pantoea \\
\hline & OVF 24 & Micrococcus \\
\hline \multirow[t]{4}{*}{ Leaf $(L)$} & OVL 9 & Bacillus \\
\hline & OVL 1 & Arthrobacter \\
\hline & OVL 12 & Bacillus \\
\hline & OVL 18 & Xanthomonas \\
\hline \multirow[t]{9}{*}{ Stem (S) } & OVS 6 & Bacillus \\
\hline & OVS 8 & Arthrobacter \\
\hline & OVS26 & Bacillus \\
\hline & OVS 2 & Curtobacterium \\
\hline & OVS10 & Bacillus \\
\hline & OVS 23 & Arthrobacter \\
\hline & OVS 9 & Pseudomonas \\
\hline & OVS 18 & Arthrobacter \\
\hline & OVS 21 & Bacillus \\
\hline \multirow[t]{4}{*}{ Soil $(T)$} & OVT 9 & Chryseobacterium \\
\hline & OVT 1 & Agrobacterium \\
\hline & OVT 2 & Agromyces \\
\hline & OVT 10 & Bacillus \\
\hline
\end{tabular}

obtained data revealed that the major effect was recorded against the CoNS strains; the inhibitory interactions observed against this group of bacteria, indeed, were strong or complete in most cases $(83.8 \%)$. In particular, the multidrug resistant strains S. epidermidis 5323, 5377 and 5321 were strongly inhibited by the endophytic isolates. Finally, stem-associated bacteria revealed the highest ability to inhibit pathogenic strains, while bulk soil associated bacteria revealed the lowest ability of inhibition. Figure 8A shows the percentage of the antagonistic activity exhibited by endophytes isolates against human pathogenic bacteria. OVS 26 showed broad spectrum of antagonistic activity against S. aureus and CoNS isolates ( $90 \%$ and $100 \%$, respectively); the endophytes OVF 10, OVL 9, OVS 6 and OVT 9 showed the capacity to be active against four strains of $K$. pneumoniae (from 16.7 to $33.3 \%$ ), while just OVS 8 was able to inhibit one $P$. aeruginosa strain. In general, all the eleven inhibitory endophytes showed degrees of antagonism against CoNS from 10 to $100 \%$. Figure $\mathbf{8 B}$ shows the TSI of the antagonistic activity exhibited by endophytes strains against $S$. aureus, CoNS, $P$. aeruginosa, K. pneumoniae human pathogenic bacteria.

\section{DISCUSSION AND CONCLUSION}

The potential of endophytes from medicinal plants to produce antibacterial, anticancer, and antifungal compounds is an emerging area in the last years (Miller et al., 2012; Maida et al., 2016; Chiellini et al., 2017; Maggini et al., 2018). O. vulgare is an aromatic and medicinal plant, whose EO has been 


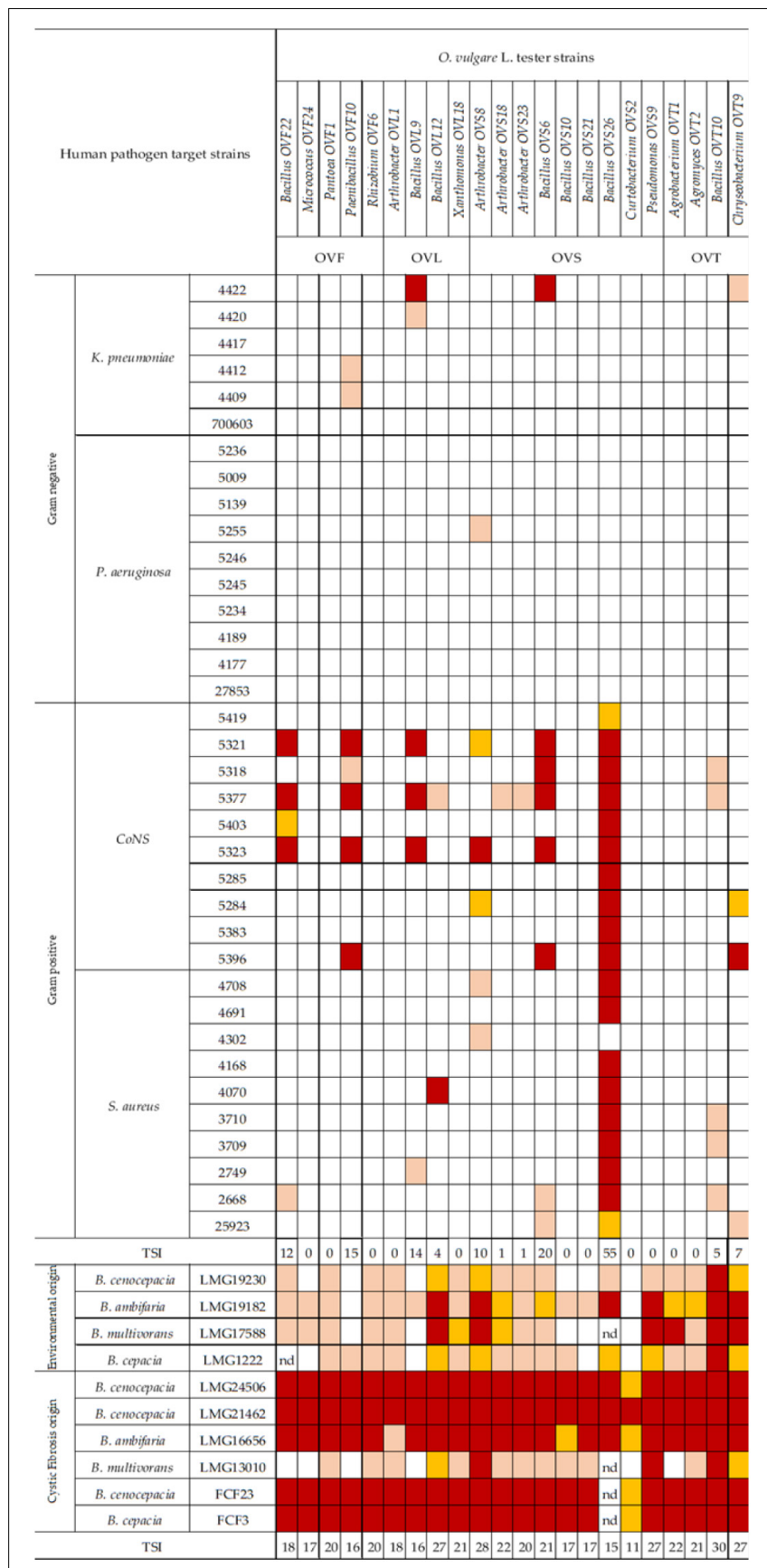

FIGURE 6 | Antagonistic interactions of $O$. vulgare associated strains against human pathogenic strains. The inhibition values reflect three different inhibition levels observed during the cross-streak experiments, that is, complete ( 3 , red), strong (2, orange), weak ( 1 , salmon), and absence ( 0 , white) of inhibition. $\mathrm{Nd}$ (not detected) refers to results that were not obtained. TSI refers to the total score of inhibition.

extensively studied because of its diverse compositions among different specimens and remarkable characteristics (Lukas et al., 2015). Ecological and environmental effects, along with genetic variability, are some of the various reasons why EOs of Origanum species show major differences in their chemical composition
(Vokou et al., 1993). The studied specimen, in particular, exhibited a germacrene $\mathrm{D} / \beta$-caryophyllene chemotype, showing a predominance of the sesquiterpene hydrocarbon fraction. Other than the volatile compounds, the aerial parts of $O$. vulgare contain a remarkable variety of therapeutic bioactive compounds, including phenolic glycosides, flavonoids, tannins, sterols and high amounts of terpenoids (Pezzani et al., 2017).

The analysis of the total microbiota, obtained though NGS analysis, revealed that flower and stem compartments host a similar endophytic community, with a high diversity of genera; on the contrary, the leaf compartment appears to be very less diverse, containing only Acinetobacter genus.

The cultivable bacterial load in $O$. vulgare different districts ranged from about $10^{2}$ to $10^{5} \mathrm{CFU} / \mathrm{g}$ of soil, stem, leaf and flowers (fresh weight); these data are in agreement with previous reports on other different medicinal plant species (Emiliani et al., 2014; Checcucci et al., 2017).

The analysis of the structure of bacterial communities revealed that the dataset obtained with RAPD analysis highlights a high level of biodiversity at the strain level, especially regarding the anatomical parts of the plant. On the contrary, fingerprinting of the isolates associated to the bulk soil revealed a more clonal community. Moreover, a very low degree of sharing $(3.1 \%)$ between the different compartments was revealed (only two haplotypes were shared between the leaf and the stem compartments), in agreement with data reported by Chiellini et al. (2014) about cultivable bacterial communities isolated from Echinacea purpurea (L.) Moench and Echinacea angustifolia (DC.).

The different genera identified through $16 \mathrm{~S}$ rDNA gene amplification in $O$. vulgare plant have been detected in other plant species too, such as E. purpurea and E. angustifolia (Chiellini et al., 2014). In this work, Bacillus resulted to be the most represented genus and it was present in all districts analyzed, while other genera were exclusively present in specific ones. Overall, the RAPD and 16S rRNA gene analysis revealed that the selection of bacteria mainly occurs at the strain level, in agreement with previous data obtained with other medicinal plants, such as Lavandula angustifolia Mill. (Emiliani et al., 2014), Echinacea purpurea and Echinacea angustifolia (Chiellini et al., 2014; Maida et al., 2016). Therefore, different endophytic bacterial species are selected not only at the root or stem level, but also within plant tissues, as the different distribution of genera could suggest. Hence, it is possible that plant might "select" specific taxa to access its compartments.

In this work we have analyzed the antibiotic resistance profile of 62 cultivable bacterial strains isolated from different anatomical parts of $O$. vulgare plant and from the bulk soil. The obtained data revealed that: (i) most of the strains showed tolerance to at least the lowest concentrations of the antibiotic streptomycin and kanamycin used, and only a few strains were able to grow in presence of low concentrations of the antibiotic chloramphenicol and ciprofloxacin; a similar trend has already been evidenced in the case of E. purpurea (Mengoni et al., 2014); (ii) only a small number of strains (2 out of 19) tolerated the lowest concentrations of rifampicin; (iii) strains associated to the bulk soil resulted resistant against the great majority of the 


\section{Antagonistic interactions against $B C C$ complex}

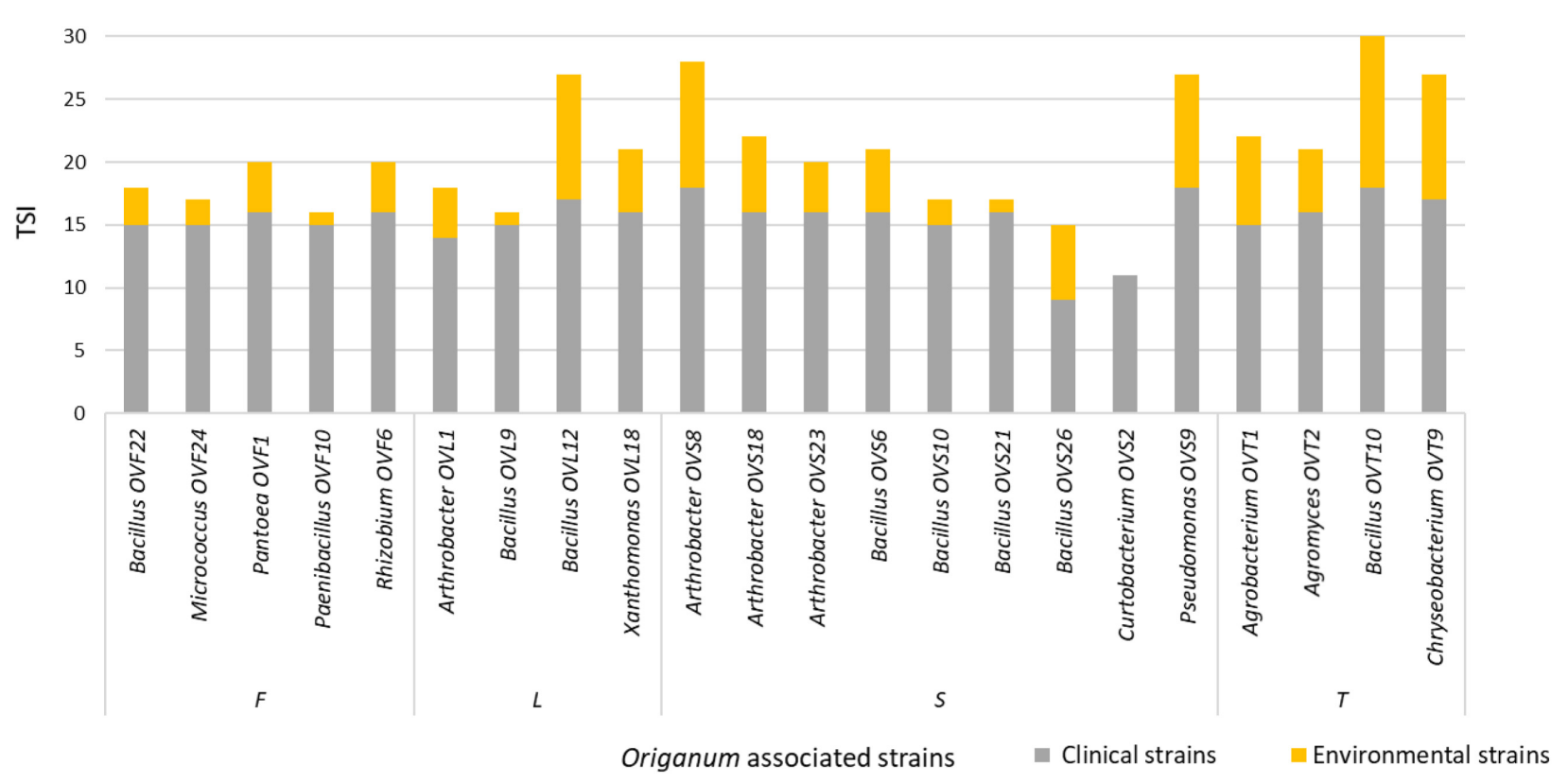

FIGURE 7 | Antagonistic interactions of $O$. vulgare associated strains against $B C C$ strains.

antibiotics tested, even at the highest concentrations used. The high tolerance to both streptomycin and kanamycin, shown by tested strains, could be due to similar resistance mechanisms. Moreover, the high resistance of strains associated to the bulk soil might be probably due to their exposure to commonly used antibiotics: in this scenario, their greater resistance to antibiotics could be explained.

Antagonistic inter and intra- compartment interactions were also evaluated. These analyses suggested that the bacterial communities from the stem and the soil compartments were particularly able to antagonize the growth of bacteria belonging to the other two compartments. Moreover, stem community revealed the highest self-inhibition levels, whereas flowerassociated bacteria revealed the lowest one. Thus, the different antagonistic activity observed could be (apparently) influenced by the ecological niche inhabited by bacteria. Overall, the obtained results suggest that antagonistic interactions between bacterial strains might play a role in driving the diverse composition of the bacterial communities in the anatomical districts of the plants. It is important to stress that the used medium could influence the inhibitory patterns, and also that in different environmental conditions the inhibitory patterns could be different: for example, strains that do not show any inhibition on plates, in vivo could be stronger antagonists, and vice versa.

Strains that exhibited high inhibitory properties were tested against multidrug resistant human pathogens. Interestingly, regarding the antagonistic activity against $\mathrm{BCC}, \mathrm{O}$. vulgare strains were much more able to inhibit the growth of BCC members isolated from CF patients than those of environmental origins. On the other hand, $47.8 \%$ of $O$. vulgare strains showed antagonistic activity against at least one human pathogenic strain among S. aureus, Coagulase-negative staphylococci (CoNS), $P$. aeruginosa and $K$. pneumoniae, with the most active isolates displaying greater capacity of inhibition mainly against Grampositive bacteria than Gram-negative ones. It has been proposed that, regarding Gram-negative bacteria, the presence of the outer polysaccharide membrane (made of various lipopolysaccharide constituents) could make them impermeable to lipophilic solutes (Silhavy et al., 2010; Naikpatil and Rathod, 2011).

At the same time, we can speculate that the different antimicrobial activity can depend on the different type of habitats that bacteria occupy: Staphylococcus aureus and CoNS are common colonizers of human epithelia, while $P$. aeruginosa and $K$. pneumoniae are opportunistic pathogens widely recovered from the environment. Hence, it is reasonable that bacteria capable of colonizing environmental habitats can exhibit intrinsic or acquired resistance against antimicrobial compounds produced by competing bacteria commonly found in the same ecological niches. Further studies should be performed to better understand this behavior.

In our opinion, data obtained in this work offer a preliminary but very promising example of the biotechnological potential of bacteria isolated from medicinal plants. In fact, the majority of the tested strains revealed a marked inhibitory effect between different compartments, widespread resistance to common antibiotics, and a strong capacity to inhibit the growth of MDR human pathogens. This last point is very important: nowadays research for new molecules active against human pathogens (MDR in particular) is one of the most important goals to achieve, mainly due to the 
A

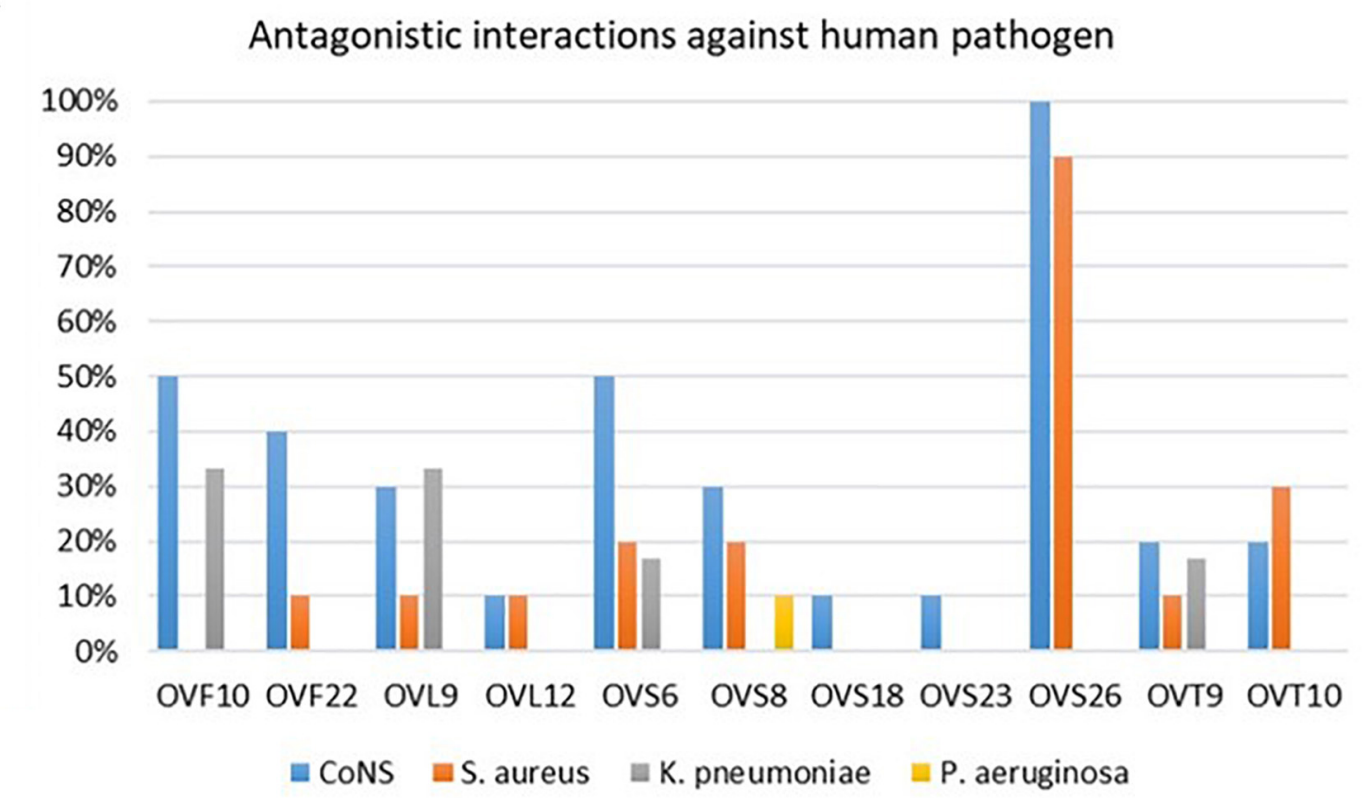

B

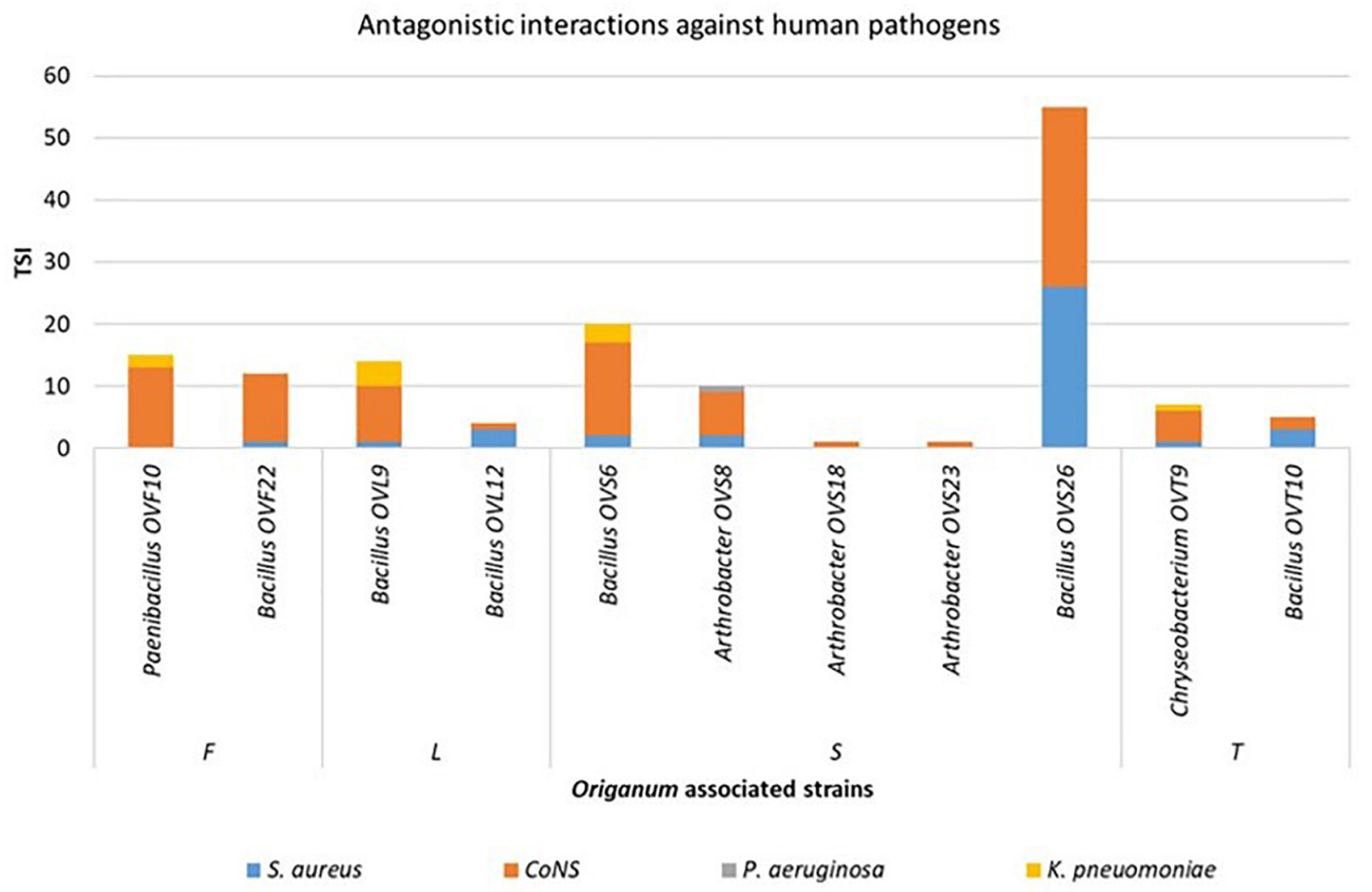

FIGURE 8 | Antagonistic activity exhibited by endophytes strains against human pathogenic bacteria (S. aureus, CoNS, P. aeruginosa, K. pneumoniae) expressed as percentage of the antagonistic activity (A) and TSI (B).

increased resistance to commercially used antibiotics, an inevitable side effect of both the unsuitable use and over prescription of antibiotics in human medicine therapy and the antibiotics released into the environment (Helal et al., 2019). As known, medicinal plants and their associated microbiome represent a natural reservoir for bioactive 
compounds of pharmacological interest. Therefore, the bioactive compounds of selected strains could be purified and then tested for their bioactivity (or cytotoxicity) on human cultures and on animal models; it could be interesting to find out if the production of antimicrobial molecules in $O$. vulgare could be dependent on its associated microbiota. Furthermore, this study suggests that antagonistic interactions between bacterial strains might play a role in driving the diverse composition of the bacterial communities in the anatomical districts of the plants.

\section{DATA AVAILABILITY STATEMENT}

The datasets generated for this study can be found in the NCBI sequence read archive PRJNA606513, Gene Bank MN811044MN811099.

\section{AUTHOR CONTRIBUTIONS}

RF, LP, AL, PB, and LC conceptualized the study and worked on the methodology. LC, CC, GB, and RA contributed to data curation and formal analysis. LC, SD, SC, AV, CC, IS, VD, RA, GB,

\section{REFERENCES}

Adams, R. P. (1995). Identification of Essential Oil Components by Gas Chromatography/Quadrupole Mass Spectroscopy. Carol Stream, IL: Allured Publishing Corporation.

Adams, R. P., Zanoni, T. A., Lara, A., Barrero, A. F., and Cool, L. G. (1997). Comparisons among Cupressus arizonica Greene, C. benthamii Endl., C. lindleyi Klotz, ex Endl. and C. lusitanica Mill, using leaf essential oils and DNA fingerprinting. J. Essent. Oil Res. 9, 303-309. doi: 10.1080/10412905.1997. 10554249

Callahan, B. J., McMurdie, P. J., Rosen, M. J., Han, A. W., Johnson, A. J. A., and Holmes, S. P. (2016). DADA2: high-resolution sample inference from Illumina amplicon data. Nat. Methods 13, 581-583. doi: 10.1038/nmeth.3869

Caporaso, J. G., Lauber, C. L., Walters, W. A., Berg-Lyons, D., Huntley, J., Fierer, N., et al. (2012). Ultra-high-throughput microbial community analysis on the Illumina HiSeq and MiSeq platforms. ISME J. 6, 1621-1624. doi: 10.1038/ismej. 2012.8

Chakravorty, S., Helb, D., Burday, M., Connell, N., and Alland, D. (2007). A detailed analysis of $16 \mathrm{~S}$ ribosomal RNA gene segments for the diagnosis of pathogenic bacteria. J. Microbiol. Methods 69, 330-339. doi: 10.1016/j.mimet. 2007.02.005

Checcucci, A., Maida, I., Bacci, G., Ninno, C., Bilia, A. R., Biffi, S., et al. (2017). Is the plant-associated microbiota of Thymus spp. adapted to plant essential oil? Res. Microbiol. 168, 276-282. doi: 10.1016/j.resmic.2016.11.004

Chiellini, C., Maida, I., Emiliani, G., Mengoni, A., Mocali, S., Fabiani, A., et al. (2014). Endophytic and rhizospheric bacterial communities isolated from the medicinal plants Echinacea purpurea and Echinacea angustifolia. Int. Microbiol. 17, 165-174. doi: 10.2436/20.1501.01.219

Chiellini, C., Maida, I., Maggini, V., Bosi, E., Mocali, S., Emiliani, G., et al. (2017). Preliminary data on antibacterial activity of Echinacea purpureaassociated bacterial communities against Burkholderia cepacia complex strains, opportunistic pathogens of Cystic Fibrosis patients. Microbiol. Res. 196, 34-43. doi: 10.1016/j.micres.2016.12.001

Cole, J. R., Wang, Q., Fish, J. A., Chai, B., McGarrell, D. M., Sun, Y., et al. (2014). Ribosomal Database Project: data and tools for high throughput rRNA analysis. Nucleic Acids Res. 42, D633-D642. doi: 10.1093/nar/gkt1244

Cosentino, S., Tuberoso, C. I., Pisano, B., Satta, M., Mascia, V., Arzedi, E., et al. (1999). In-vitro antimicrobial activity and chemical composition of Sardinian and SB carried out the investigation. RF, LP, AL, and FF helped with project administration. FF was responsible for the resource. LC, SD, SC, AV, AL, CC, IS, VD, LP, RA, and GB validated the study. LC, CC, and RA wrote the original draft. LC, AV, SD, SC, CC, AL, VD, LP, RA, MD, VM, PB, AM, and RF reviewed and edited the manuscript.

\section{FUNDING}

This work was supported by Tuscany Region (Italy; Resolu-tion n. 1224/2016 "Medicine Complementari") and by Fondazione Cassa di Risparmio di Firenze (project \#2016.0936, Herbiome: new antibiotic molecules from endophytic bacteria isolated from medicinal plants). The funding sources had no involvement in any part of the study.

\section{SUPPLEMENTARY MATERIAL}

The Supplementary Material for this article can be found online at: https://www.frontiersin.org/articles/10.3389/fmicb. 2020.00862/full\#supplementary-material

Thymus essential oils. Lett. Appl. Microbiol. 29, 130-135. doi: 10.1046/j.1472765x.1999.00605

Davies, N. W. (1990). Gas chromatographic retention indices of monoterpenes and sesquiterpenes on Methyl Silicon and Carbowax 20M phases. J. Chromatogr. 503, 1-24.

De Mastro, G., Tarraf, W., Verdini, L., Brunetti, G., and Ruta, C. (2017). Essential oil diversity of Origanum vulgare L. populations from Southern Italy. Food Chem. 235, 1-6. doi: 10.1016/j.foodchem.2017.05.019

Di Cello, F., and Fani, R. (1996). A molecular strategy for the study of natural bacterial communities by PCR-based techniques. Minerva Biotecnol. 8, 126134.

Emiliani, G., Mengoni, A., Maida, I., Perrin, E., Chiellini, C., Fondi, M., et al. (2014). Linking bacterial endophytic communities to essential oils: clues from Lavandula angustifolia Mill. Evid. Based Complement. Alternat. Med. 2014:650905. doi: 10.1155/2014/650905

Gunatilaka, A. A. (2006). Natural products from plant-associated microorganisms: distribution, structural diversity, bioactivity, and implications of their occurrence. J. Nat. Prod. 69, 509-526. doi: 10.1021/np058128n

Hall, T. A. (1999). BioEdit: a user-friendly biological sequence alignment editor and analysis program for Windows 95/98/ NT. Nucleic Acids Symp. 41, 95-98.

Hanci, S., Sahin, S., and Yilmaz, L. (2003). Isolation of volatile oil from thyme (Thymbra spicata) by steam distillation. Nahrung 47, 252-255. doi: 10.1002/ food.200390059

Helal, I. M., El-Bessoumy, A., Al-Bataineh, E., Joseph, M. R. P., Rajagopalan, P., Chandramoorthy, H. C., et al. (2019). Antimicrobial efficiency of essential oils from traditional medicinal plants of asir region, saudi arabia, over drug resistant isolates. Biomed Res. Int. 2019:8928306. doi: 10.1155/2019/8928306

Herlemann, D. P. R., Labrenz, M., Jürgens, K., Bertilsson, S., Waniek, J. J., and Andersson, A. F. (2011). Transitions in bacterial communities along the 2000 $\mathrm{km}$ salinity gradient of the Baltic Sea. ISME J. 5, 1571-1579. doi: 10.1038/ismej. 2011.41

Huse, S. M., Dethlefsen, L., Huber, J. A., Welch, D. M., Relman, D. A., and Sogin, M. L. (2008). Exploring microbial diversity and taxonomy using SSU rRNA hypervariable tag sequencing. PLoS Genet. 4:e1000255. doi: 10.1371/journal. pgen.1000255

Jennings, W., and Shibamoto, T. (1982). Qualitative Analysis of Flavor and Fragrance Volatiles by Glass Capillary Gas Chromatography. New York, NY: Academic Press. 
Köberl, M., Schmidt, R., Ramadan, E. M., Bauer, R., and Berg, G. (2013). The microbiome of medicinal plants: diversity and importance for plant growth, quality, and health. Front. Microbiol. 4:400. doi: 10.3389/fmicb.2013.00400

Kozich, J. J., Westcott, S. L., Baxter, N. T., Highlander, S. K., and Schloss, P. D. (2013). Development of a dual-index sequencing strategy and curation pipeline for analyzing amplicon sequence data on the MiSeq Illumina sequencing platform. Appl. Environ. Microbiol. 79, 5112-5120. doi: 10.1128/AEM.01043-13

Kumar, S., Stecher, G., Li, M., Knyaz, C., and Tamura, K. (2018). MEGA X: molecular evolu-tionary genetics analysis across computing platforms. Mol. Biol. Evol. 35, 1547-1549. doi: 10.1093/molbev/msy096

Lam, K. S. (2007). New aspects of natural products in drug discovery. Trends Microbiol. 15, 279-289. doi: 10.1016/j.tim.2007.04.001

Lambert, R. J., Skandamis, P. N., Coote, P. J., and Nychas, G. J. (2001). A study of the minimum inhibitory concentration and mode of action of oregano essential oil, thymol and carvacrol. J. Appl. Microbiol. 91, 453-462. doi: 10.1046/j.13652672.2001.01428.x

Lukas, B., Schmiderer, C., and Novak, J. (2015). Essential oil diversity of European Origanum vulgare L. (Lamiaceae). Phytochemistry 119, 32-40. doi: 10.1016/j. phytochem.2015.09.008

Maggini, V., Bandeira Reidel, R. V., De Leo, M., Mengoni, A., Gallo, E. R., Miceli, E., et al. (2019a). Volatile profile of Echinacea purpurea plants after in vitro endophyte infection. Nat. Prod. Res. 25, 1-6. doi: 10.1080/14786419. 2019.1579810

Maggini, V., De Leo, M., Granchi, C., Tuccinardi, T., Mengoni, A., Gallo, E. R., et al. (2019b). The influence of Echinacea purpurea leaf microbiota on chicoric acid level. Sci. Rep. 9:10897. doi: 10.1038/s41598-019-47329-8

Maggini, V., Mengoni, A., Bogani, P., Firenzuoli, F., and Fani, R. (2020). Promoting model systems of microbiota-medicinal plant interactions. Trends Plant Sci. 25, 223-225. doi: 10.1016/j.tplants.2019.12.013

Maggini, V., Miceli, E., Fagorzi, C., Maida, I., Fondi, M., Perrin, E., et al. (2018). Antagonism and antibiotic resistance drive a species-specific plant microbiota differentiation in Echinacea spp. FEMS Microbiol. Ecol. 94:fiy118. doi: 10.1093/ femsec/fiy 118

Maida, I., Chiellini, C., Mengoni, A., Bosi, E., Firenzuoli, F., Fondi, M., et al. (2016). Antagonistic interactions between endophytic cultivable bacterial communities isolated from the medicinal plant Echinacea purpurea. Environ. Microbiol. 18, 2357-2365. doi: 10.1111/1462-2920.12911

Malik, S., de Mesquita, L. S. S., Silva, C. R., de Mesquita, J. W. C., de Sá Rocha, E., Bose, J., et al. (2019). Chemical profile and biological activities of essential oil from Artemisia vulgaris L. cultivated in Brazil. Pharmaceuticals 12:E49. doi: $10.3390 /$ ph12020049

Martin, M. (2011). Cutadapt removes adapter sequences from high-throughput sequencing reads. EMBnet J. 17, 10-12. doi: 10.14806/ej.17.1.200

Masada, Y. (1976). Analysis of Essential Oils by Gas Chromatography and Mass Spectrometry. New York, NY: John Wiley \& Sons, Inc.

Mendes, R., Garbeva, P., and Raaijmakers, J. M. (2013). The rhizosphere microbiome: significance of plant beneficial, plant pathogenic, and human pathogenic microorganisms. FEMS Microbiol. Rev. 37, 634-663. doi: 10.1111/ 1574-6976.12028

Mengoni, A., Maida, I., Chiellini, C., Emiliani, G., Mocali, S., Fabiani, A., et al. (2014). Antibiotic resistance differentiates Echinacea purpurea endophytic bacterial communities with respect to plant organs. Res. Microbiol. 165, 686694. doi: 10.1016/j.resmic.2014.09.008

Miller, K. I., Qing, C., Sze, D. M., Roufogalis, B. D., and Neilan, B. A. (2012). Culturable endophytes of medicinal plants and the genetic basis for their bioactivity. Microb. Ecol. 64, 431-449. doi: 10.1007/s00248-012-0044-8

Mockute, D., Bernotiene, G., and Judzentiene, A. (2001). The essential oil of Origanum vulgare L. ssp. vulgare growing wild in Vilnius district (Lithuania). Phytochemistry 57, 65-69. doi: 10.1016/S0031-9422(00) 00474-X

Mori, E., Liò, P., Daly, S., Damiani, G., Perito, B., and Fani, R. (1999). Molecular nature of RAPD markers from Haemophilus influenzae Rd genome. Res. Microbiol. 150, 83-93. doi: 10.1016/s0923-2508(99) 80026-6
Murali, A., Bhargava, A., and Wright, E. S. (2018). IDTAXA: a novel approach for accurate taxonomic classification of microbiome sequences. Microbiome 6:140. doi: 10.1186/s40168-018-0521-5

Naikpatil, S. V., and Rathod, J. L. (2011). Selective isolation and antimicrobial activity of rare actinomycetes from mangrove sediment of Karwar. J. Ecobiotechnol. 3, 48-53.

Petrosino, J. F., Highlander, S., Luna, R. A., Gibbs, R. A., and Versalovic, J. (2009). Metagenomic pyrosequencing and microbial identification. Clin. Chem. 55, 856-866. doi: 10.1373/clinchem.2008.107565

Pezzani, R., Vitalini, S., and Iriti, M. (2017). Bioactivities of Origanum vulgare L.: an update. Phytochem. Rev. 16, 1253-1268. doi: 10.1007/s11101-017-9535-z

Philippot, L., Raaijmakers, J. M., Lemanceau, P., and van der Putten, W. H. (2013). Going back to the roots: the microbial ecology of the rhizosphere. Nat. Rev. Microbiol. 11, 789-799. doi: 10.1038/nrmicro3109

Qi, X., Wang, E., Xing, M., Zhao, W., and Chen, X. (2012). Rhizosphere and non-rhizosphere bacterial community composition of the wild medicinal plant Rumex patientia. World J. Microbiol. Biotechnol. 28, 2257-2265. doi: 10.1007/ s11274-012-1033-2

Quast, C., Pruesse, E., Yilmaz, P., Gerken, J., Schweer, T., Yarza, P., et al. (2013). The SILVA ribosomal RNA gene database project: improved data processing and web-based tools. Nucleic Acids Res. 41, D590-D596. doi: 10.1093/nar/gks1219

Quispel, A. (1992). “A search of signals in endophytic microorganisms," in Molecular Signals in Plant-Microbe Communications, ed. D. P. S. Verma (Boca Raton, FL: CRC Press), 471-491.

Reinhold-Hurek, B., and Hurek, T. (2011). Living inside plants: bacterial endophytes. Curr. Opin. Plant Biol. 14, 435-443. doi: 10.1016/j.pbi.2011.04.004

Saab, A. M., Gambari, R., Sacchetti, G., Guerrini, A., Lampronti, I., Tacchini, M., et al. (2018). Phytochemical and pharmacological properties of essential oils from Cedrus species. Nat. Prod. Res. 32, 1415-1427. doi: 10.1080/14786419. 2017.1346648

Sahoo, N., Padmavati, M., and Satyahari, D. (2010). Herbal drugs: standards and regulation. Fitoterapia 81, 462-471. doi: 10.1016/j.fitote.2010.02.001

Saiman, L., Siegel, J., and Cystic Fibrosis Foundation Consensus Conference on Infection Control Participants (2003). Infection control recommendations for patients with cystic fibrosis: microbiology important pathogens, and infection control practices to prevent patient-to-patient transmission. Am. J. Infect. Control 31(Suppl. 3), S1-S62. doi: 10.1067/mic.2003.78

Shityakova, S., Bigdelianb, E., Hussein, A., Bilal Hussaine, M., Tripathif, T. C., Khan, M. U., et al. (2019). Phytochemical and pharmacological attributes of piperine: a bioactive ingredient of black pepper. Eur. J. Med. Chem. 176, 149-161. doi: 10.1016/j.ejmech.2019.04.002

Silhavy, T. J., Kahne, D., and Walker, S. (2010). The bacterial cell envelope. Cold Spring Harb. Perspect. Biol. 2:a000414. doi: 10.1101/cshperspect.a000414

Swigar, A. A., and Silverstein, R. M. (1992). Monoterpenes. Milwaukee, WI: Aldrich Chemical Company.

Vokou, D., Kokkini, S., and Bessiere, J.-M. (1993). Geographic variation of Greek oregano (Origanum vulgare ssp. hirtum) essential oils. Biochem. Syst. Ecol. 21, 287-295.

Werker, E., Putievsky, E., and Ravid, U. (1985). The essential oils and glandular hairs in different chemotypes of Origanum vulgare L. Ann. Bot. 55, 793-801. doi: 10.1093/oxfordjournals.aob.a086958

Conflict of Interest: The authors declare that the research was conducted in the absence of any commercial or financial relationships that could be construed as a potential conflict of interest.

Copyright (C) 2020 Castronovo, Calonico, Ascrizzi, Del Duca, Delfino, Chioccioli, Vassallo, Strozza, De Leo, Biffi, Bacci, Bogani, Maggini, Mengoni, Pistelli, Lo Nostro, Firenzuoli and Fani. This is an open-access article distributed under the terms of the Creative Commons Attribution License (CC BY). The use, distribution or reproduction in other forums is permitted, provided the original author(s) and the copyright owner(s) are credited and that the original publication in this journal is cited, in accordance with accepted academic practice. No use, distribution or reproduction is permitted which does not comply with these terms. 